\title{
Redesigning Choice Architecture for the College Selection and Application Process for High School Juniors
}

Lindsey Estep

West Virginia University

Follow this and additional works at: https://researchrepository.wvu.edu/etd

\section{Recommended Citation}

Estep, Lindsey, "Redesigning Choice Architecture for the College Selection and Application Process for High School Juniors" (2014). Graduate Theses, Dissertations, and Problem Reports. 453.

https://researchrepository.wvu.edu/etd/453

This Thesis is protected by copyright and/or related rights. It has been brought to you by the The Research Repository @ WVU with permission from the rights-holder(s). You are free to use this Thesis in any way that is permitted by the copyright and related rights legislation that applies to your use. For other uses you must obtain permission from the rights-holder(s) directly, unless additional rights are indicated by a Creative Commons license in the record and/ or on the work itself. This Thesis has been accepted for inclusion in WVU Graduate Theses, Dissertations, and Problem Reports collection by an authorized administrator of The Research Repository @ WVU. For more information, please contact researchrepository@mail.wvu.edu. 


\title{
Redesigning Choice Architecture for the College Selection and Application Process for High School Juniors
}

\author{
Lindsey Estep
}

\author{
Thesis submitted to the \\ College of Creative Arts School of Art and Design \\ West Virginia University \\ in partial fulfillment of the requirements \\ for the degree of \\ Master of Arts \\ in \\ Art \& Design
}

\author{
Eve Faulkes, M.F.A., Chair \\ Kofi Opoku, M.F.A. \\ Michael Sherwin, M.F.A. \\ Department of Graphic Design \\ Morgantown, West Virginia \\ 2014
}

Key Words: choice architecture, data visualization, college selection, college application, knowledge pyramid, design

Copyright 2014 Lindsey Estep 


\section{ABSTRACT}

\section{Redesigning Choice Architecture for the College Selection and Application Process for High School Juniors}

\section{Lindsey Estep}

Choice architecture, a term coined in the 2008 book Nudge: Improving Decisions About Health, Wealth, and Happiness by behavioral scientist Richard H. Thaler and professor of law Cass R. Sunstein, is the belief that no choice can be neutral because the way in which a choice is presented influences the decision-maker. Designers, perfectly positioned to structure choices in both print and digital format, should equally embrace this role and handle it with great responsibility. Rather than use the power to structure choice architecture to bolster consumerism, we should instead harness the opportunity to help individuals make choices that improve their health, finances, relationships, and prospects - thereby creating change that could scale to families, communities, states, and even entire nations.

This project is an exploration of the ways a designer can structure the choice architecture for the first major life decision many young folks face - which college to attend. Considered within the context of the current West Virginia college landscape, and using qualitative and quantitative data gathered from a group representing the target audience, the project provides a model for leading students through the complex process of evaluating options and making a decision that is best suited to their situation, without encroaching on their freedom of choice. 


\section{ACKNOWLEDGEMENTS}

I would like to thank my fellow graduate graphic design students, Lauren Schiefelbein, Forrest Conroy, and current faculty member Kofi Opoku for their support and feedback during my time here. Thanks also to members of my commitee - Eve Faulkes, Joe Galbreath, Michael Sherwin, Kofi Opoku, and former committee member Chris Barr - along with faculty member Joe Lupo, adjunct faculty Jack Moffett, and former faculty member Erika Osborne for providing a rich and challenging education full of new experiences.

To my family and friends, thank you for your encouragement. And to my husband Greg, thank you for all those nights you washed dishes so that I could get in a few more minutes of work. It did not go unnoticed. :)

I have been so blessed with opportunities in my personal and professional life that could have only come from above. 


\section{TABLE OF CONTENTS}

List of Tables \& Figures.............................................................

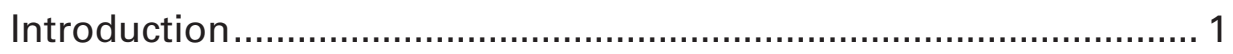

Structuring the Choice Task........................................................ 7

Describing the Choice Options ................................................ 15

Going Back to High School .....................................................19

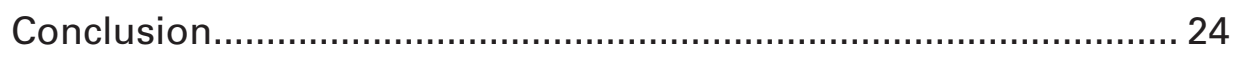

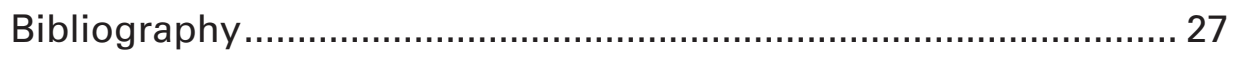

Appendix A. DIY Guide to the Epic College Decision .................... 29 


\section{LIST OF TABLES \& FIGURES}

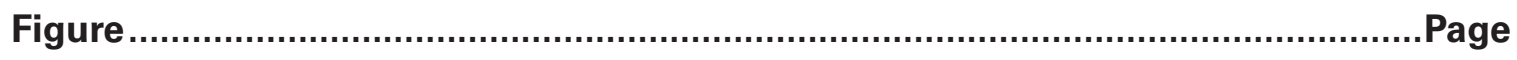

Figure 1. "Combating Poverty in the Mountain State" choropleth map .................... 1

Figure 2. Screenshots of college websites ........................................................

Figure 3. Shedroff's Data, Information, Knowledge, Wisdom continuum .................6

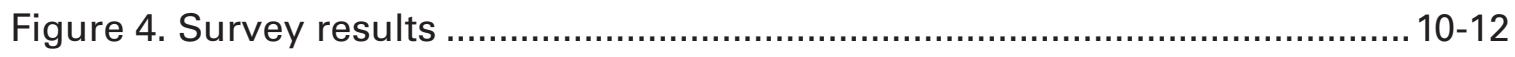

Figure 5. Location and size infographic ........................................................ 18

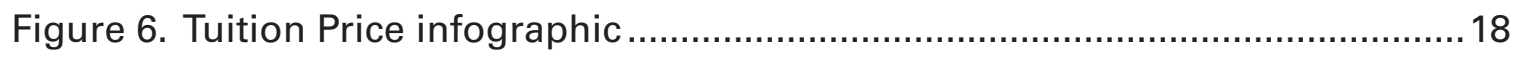

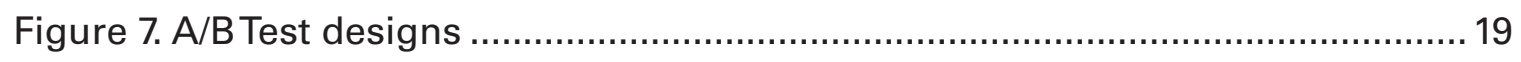

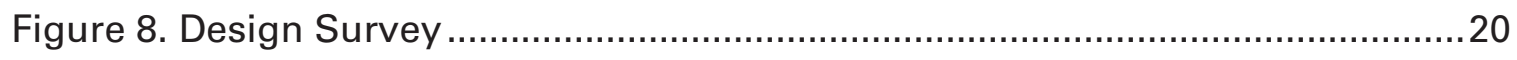

Figure 9. Samples of design inspiration ...................................................22, 23

Figure 10. Shedroff's annotated knowledge continuum...................................25

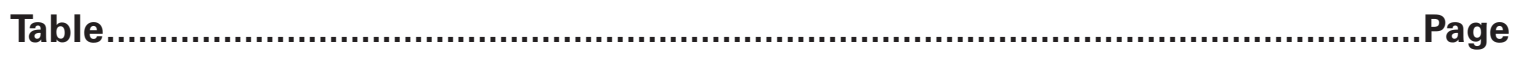

Table 1. WV Degree Granting Institutions ...................................................... 8

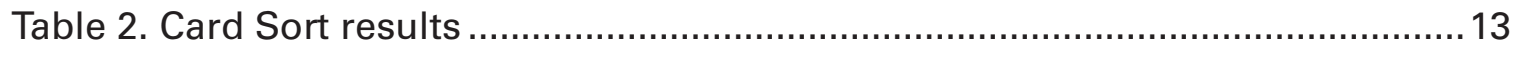




\section{INTRODUCTION}

According to the National Center for Higher Education Management Systems, in 2011 only $20.4 \%$ of West Virginia residents ages 25-64 had a Bachelor degree or higher, the lowest rate in the United States (NCHEMS 2011). Furthermore, West Virginia has one of the highest percentages of population living below the poverty line when compared to other states (Bishaw 2012). A choropleth map titled "Combating Poverty in the Mountain State" (Figure 1) that presents evidence that one's chance of living below the poverty line decreases as education increases, served as the primary driver to explore college-going rates in West Virginia. A few counties on this map stood out among their peers, one of which was Gilmer County, located near the center of the state. Gilmer County was nearly the worst county out of a state that was nearly the worst in the nation. While this map seemingly indicates the opportunity for a better financial future with a college education, just over half of Gilmer County High School students are going to college (West Virginia Higher Education Policy Commission 2014). This is made even more perplexing by the fact that there is a respected and affordable four-year college located less than one mile from the high school itself.

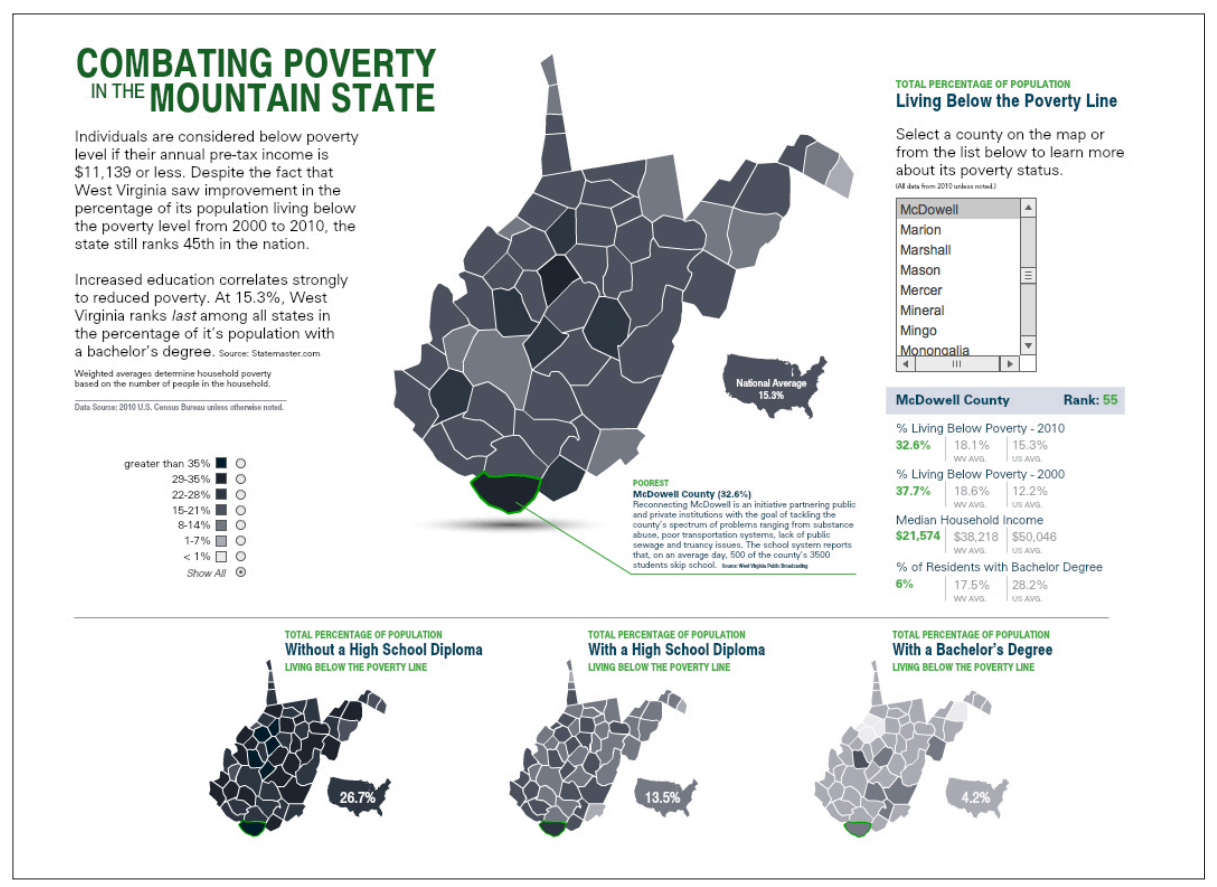

Figure 1. Choropleth map showing percentage of population living below the poverty level by degree level. Lindsey Estep, 2012. 
There are many reasons that high school graduates do not continue on to college. Among those reasons, students may claim:

"I can't afford to go to college." (COST)

"I could be making money for the next four years instead." (LOST EARNINGS)

"I barely made it through high school." (NOT SMART ENOUGH)

"I'll go once I figure out what I want to do for a career." (NOT SURE WHAT TO STUDY)

"I have no use for Art History." (ONLY NEED CERTAIN SKILLS)

"It's too much work just to get to college." (DON'T KNOw WHERE TO START)

While all of these reasons are worth exploring, this project seeks to provide a solution to the last justification on that list by removing unnecessary complexity in the process of selecting and applying to a college. As many of us have experienced in life, just breaking through the inertia or fear to get started actually is the most difficult part of a difficult task. The average seventeenyear-old evaluates options, makes choices, and adheres to requirements every day. While these same tasks are central to the college selection and application process-and should therefore be familiar to high school students-the primary difference between making a college selection and the other daily choices that a student makes, is that West Virginia college choices are not presented in a way that facilitates a fair or easy comparison between schools. Furthermore, the timeline for receiving feedback from those choices is far longer than seventeen year-olds are accustomed to in their daily lives. All of a sudden, seventeen year olds are thrust into a world of months-long timelines, FAFSAs, and making a decision that will likely affect them for the remainder of their lives. To make these life-altering choices, students must spend hours scouring the internet or marketing materials for pieces of information like tuition price, 
size of school, distance from home, and scholarships available along with

their respective eligibility requirements. Oftentimes these critical pieces of

information are found three or more levels deep on a website and in a different

location on each individual college's site (Figure 2.).

Figure 2. Beginning from a school's homepage, below is a demonstration of the unique path, and the number of mouse clicks necessary to find out how many students are enrolled in that institution.

\section{WEST VIRGINIA UNIVERSITY}

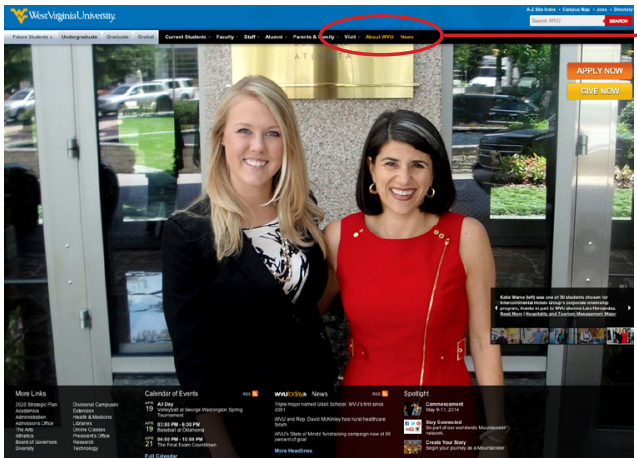

Click ABOUT WVU

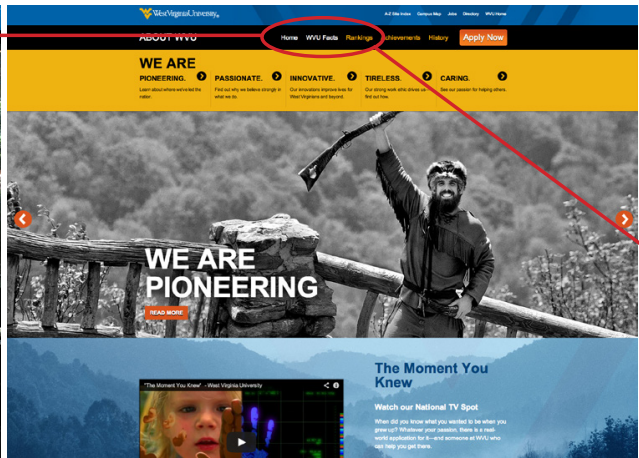

Click WVU FACTS

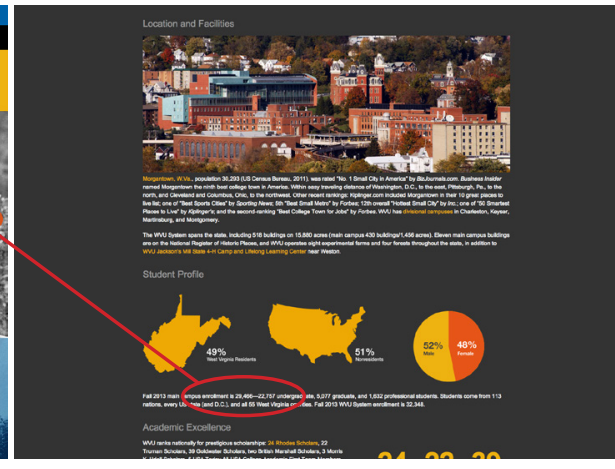

Scroll part way down the page

BLUE RIDGE COMMUNITY ANDTECHNICAL COLLEGE

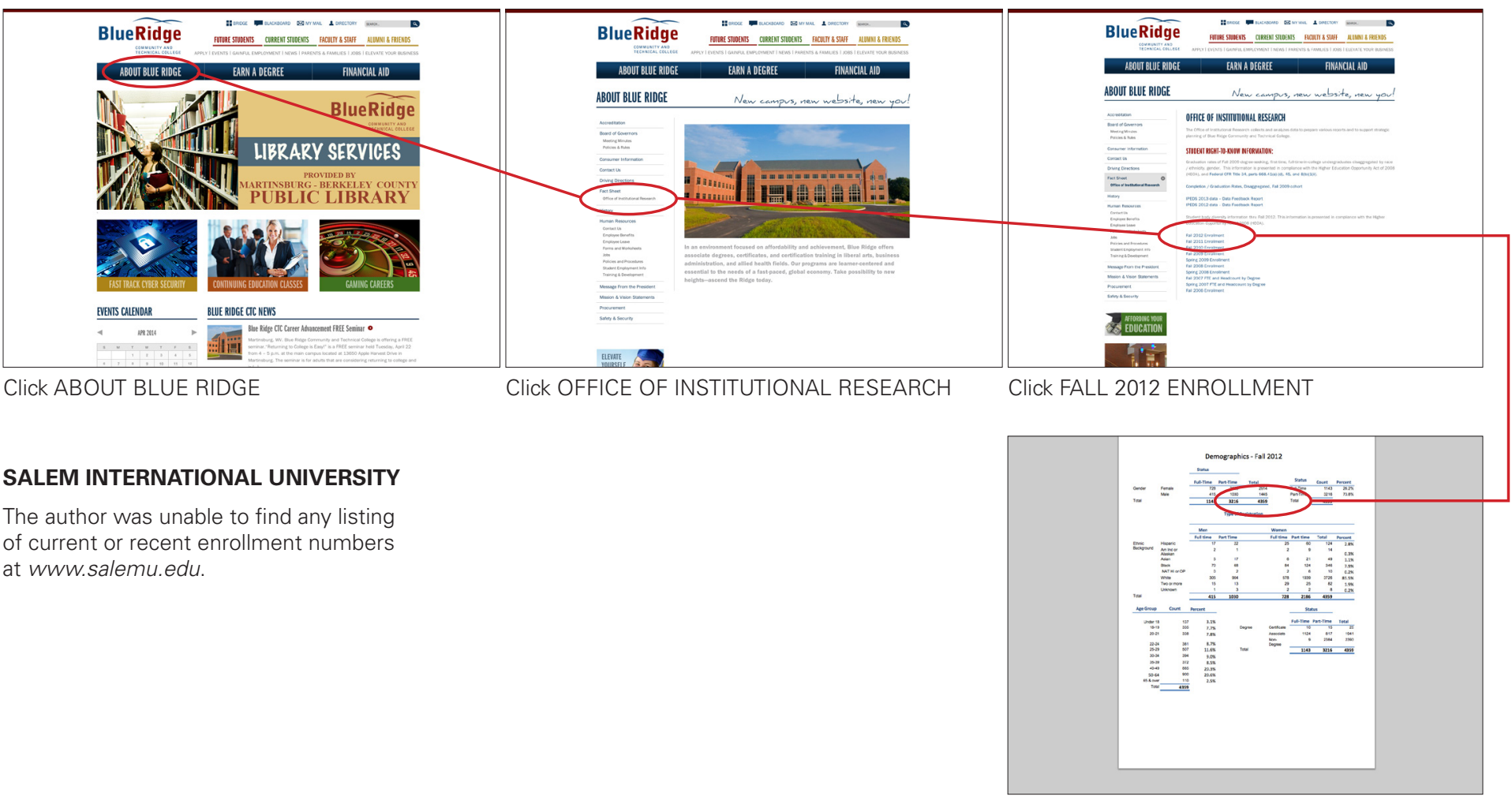

PDF document automatically launches 
In their book Nudge: Improving Decisions About Health, Wealth, and Happiness, behavioral scientist Richard Thaler and Harvard professor of law Cass Sunstein theorize that the average person would benefit from guidancein the form of clearly articulated options-for decisions that are "difficult and rare, for which they do not get prompt feedback, and when they have trouble translating aspects of the situation into terms that they can easily understand." (Thaler 2009) Deciding on a post-secondary school path certainly fits that description. Selecting a college for the first time is a decision that only happens once in an individual's lifetime, feedback from that decision may not materialize until years after a student has completed college, and determining aspects like the tuition one can afford to repay through loans is likely to be a concept altogether foreign to teenagers who may not even have bank accounts. Thaler and Sunstein call providing this guidance a nudge and advocate giving nudges in the form of improved choice architecture:

A good system of choice architecture helps people to improve their ability to map and hence to select options that will make them better off. One way to do this is to make the information about various options more comprehensible, by transforming numerical information into units that translate more readily into actual use. (Thaler 2009)

Consider the simple example of tuition prices. While this is one of the easiest pieces of information for prospective students to find, some colleges list a tuition price that represents a full school year (not including summer), some list a price that represents only one semester, some list quarter prices, some list price-by-credit hour, and some list a combination of semester and credit hour prices. In a few instances, schools will list tuition and fees as a single number, while others list only the tuition price and additional fees are charged separately. This makes comparing schools difficult without doing some math and paying close attention to details. 
It is true that a host of tools and websites exist that allow a student to compare colleges across the nation based on statistics like cost, graduation rate, student-to-faculty ratio and other standardized data. However, there is no all-in-one tool to help students evaluate and compare West Virginia colleges specifically, and in a way that is both fair and in terms or a context that teen students relate to. If data about West Virginia college options were easier to compare and understand, high school students in the state could be better equipped to choose a college that best fits their unique situation. Students would be less likely to attend a college that is not a good match, and less likely to miss out on the opportunity to attend college simply because they were illinformed about their options.

While poorly executed choice architecture puts all students at a disadvantage, it likely has a disproportionate effect on students from underprivileged backgrounds. Attending college and earning a degree has the potential to be the single, most impactful accomplishment a disadvantaged student has of escaping poverty, yet poor architecture hurts their chances of even getting there. Thaler and Sunstein agree, saying, "when markets get more complicated, unsophisticated and uneducated shoppers will be especially disadvantaged by the complexity." (Thaler 2009)

The goal of this project was to aid West Virginia high school students in choosing a college by applying and adapting Thaler and Sunstein's theories for an audience significantly younger than the trial groups outlined in Nudge and subsequent experiments. It is my belief that presenting data about each of West Virginia's forty-one higher education institutions in a visual, infographic format will help high school juniors evaluate and compare their postsecondary options and select a school that is the best fit for their individual situation and need in the same way that Thaler and Sunstein's experiments helped make credit card fees more comprehensible to adult customers (Thaler 2009). 
Converting decision-making data like cost of attendance, size and enrollment, and number of programs of study into infographics will restructure the information architecture by: bringing together scattered pieces of information into a central location; allowing for direct comparison of all options; and structuring information in a visual and verbal format that students relate to. This restructuring will help students move through the knowledge pyramid (figure 3) by analyzing data, converting it to information, and then building knowledge by giving that information context. The result of this redesigned choice architecture will be that students can more effectively navigate the West Virginia college search and application process and end up in colleges best suited to their needs. Reduced complexity would open the door for more students to make the transition from high school to college, potentially leading to long-ranging socio-economic impacts on the state by way of a workforce better prepared to meet the requirements for higher paying jobs.

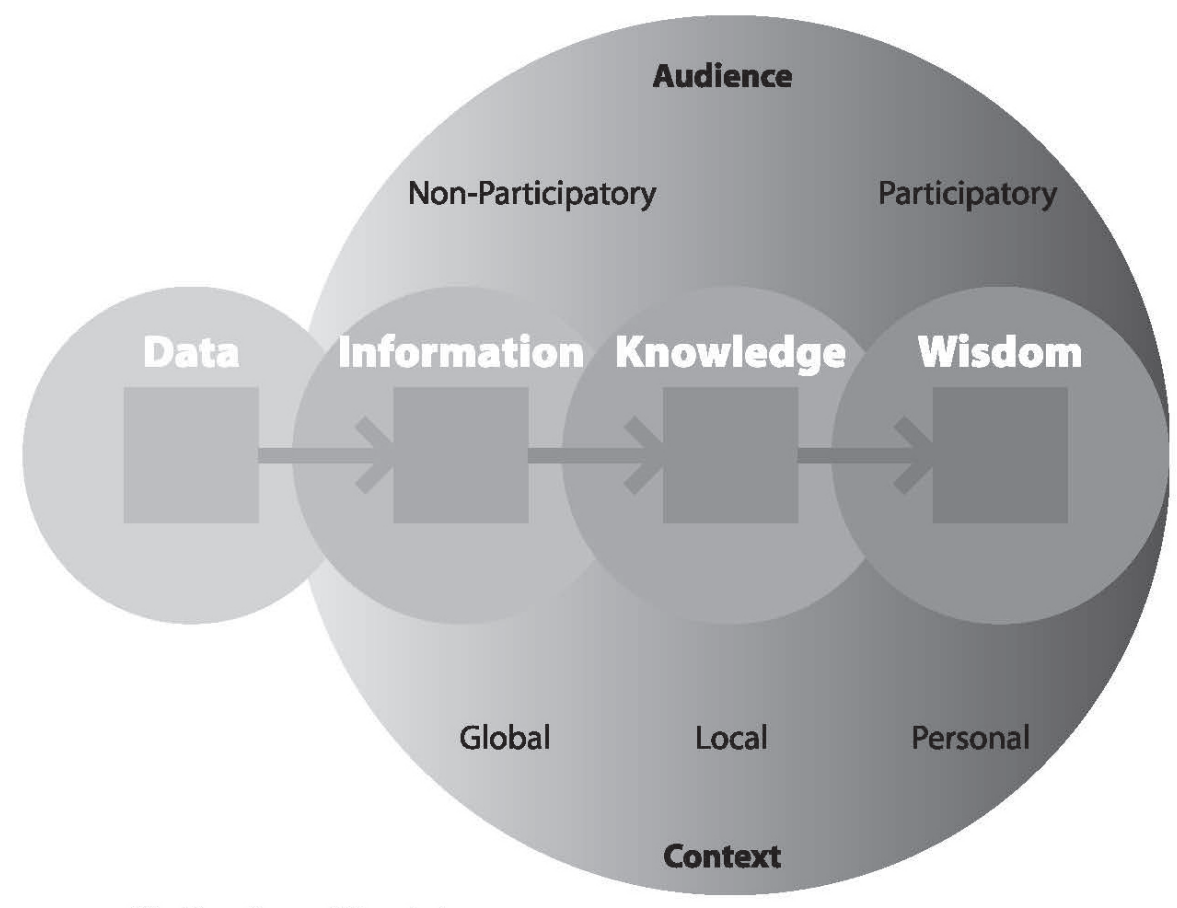

Figure 3. The Data, Information, Knowledge, Wisdom (DIKW) pyramid interpreted as a continuum by Nathan Shedroff. (Shedroff 1994). 


\section{STRUCTURING THE CHOICE TASK}

Central to choice architecture is selecting the number of options to present to decision makers. While it is widely recognized that too many options can overwhelm a user and then stifle decision-making, it is critical to include all viable options so as to avoid creating bias. In the case of West Virginia colleges, it was discovered that forty-one institutions grant either Associate or Baccalaureate degrees (table 1). Despite the fact that there is a wide range of quality among those particular institutions, it was important to include all as possibilities for West Virginia students seeking a degree. Other institutions that offered only certificates or only graduate degrees were excluded from the project so as not to dilute the options that were most relevant to students seeking a college degree.

In the paper titled "Beyond Nudges: Tools of a choice architecture," Eric J. Johnson and his team posit that there are two categories of tools available to choice architects: those for structuring the choice task (what to present) and for describing the choice options (how to present).

[...] the choice architect needs to balance two criteria: first that more options increase the chances of offering a preference match to the consumer, and second that more options places a greater cognitive burden on consumers because of the additional need to evaluate options. Thus, to answer this question of balance, we should be concerned about the willingness of the decision-maker to engage in the choice process, the decision-maker's satisfaction with the decision process, and more generally the nature of the processes that will be used to make the decision. (Johnson 2013) 
Table 1. Basic information for each of West Virginia's forty-one Associate and Baccalaureate degree-granting institutions. Cost, enrollment, and degree data from the National Center for Education Statistics College Navigator (U.S. Department of Education 2014), all other information from individual college websites.

\begin{tabular}{|c|c|c|c|c|c|c|c|c|c|c|c|}
\hline INSTITUTION NAME & ADDRESS & CITY & WEBSITE & $\begin{array}{l}\text { PUBLIC/P } \\
\text { RIVATE }\end{array}$ & & TYPE & & $\begin{array}{l}\text { REES } \\
\text { ERED }\end{array}$ & $\begin{array}{l}\text { TUITION } \\
\text { (2012-13 or } \\
24 \text { credit hrs) }\end{array}$ & $\begin{array}{l}\text { ROOM \& } \\
\text { BOARD } \\
\text { (2012-13) }\end{array}$ & $\begin{array}{l}\text { STUDENT } \\
\text { POPULATION }\end{array}$ \\
\hline Alderson Broaddus College & 101 College Park Dr & Philippi & www.ab.edu & Private & & 4 year & A & B & $\$ 22,740.00$ & $\$ 7,236.00$ & 826 \\
\hline American Public University System & N. George St. & Charles Town & www.apus.edu & Private & for-profit & 4 year & A & B & $\$ 6,400.00$ & none & 58,115 \\
\hline Appalachian Bible College & 161 College Dr & Mount Hope & www.abc.edu & Private & & 4 year & A & B & $\$ 12,680.00$ & $\$ 6,570.00$ & 302 \\
\hline Bethany College & 1 Main Street & Bethany & www.bethanywv.edu & Private & & 4 year & & B & $\$ 24,780.00$ & $\$ 9,546.00$ & 842 \\
\hline Blue Ridge Community and Technical College & 13650 Apple Harvest Drive & Martinsburg & www.blueridgectc.edu & Public & & 2 year & A & & $\$ 3,120.00$ & none & 4,360 \\
\hline Bluefield State College & 219 Rock Street & Bluefield & www.bluefieldstate.edu/ & Public & & 4 year & A & B & $\$ 5,180.00$ & none & 1,935 \\
\hline Bridgemont Community and Technical College & 619 2nd Avenue & Montgomery & www.bridgemont.edu & Public & & 2 year & A & & $\$ 3,934.00$ & $\$ 3,793.00$ & 1,070 \\
\hline Concord University & Vermillion Street PO Box 10 & Athens & www.concord.edu/ & Public & & 4 year & A & B & $\$ 5,716.00$ & $\$ 7,386.00$ & 2,834 \\
\hline Davis \& Elkins College & 100 Campus Drive & Elkins & www.dewv.edu & Private & & 4 year & A & B & $\$ 23,820.00$ & $\$ 8,350.00$ & 818 \\
\hline Eastern Community and Technical College & 316 Eastern Drive & Moorefield & www.easternwv.edu & Public & & 2 year & A & & $\$ 2,424.00$ & none & 822 \\
\hline Fairmont State University & 1201 Locust Avenue & Fairmont & www.fairmontstate.edu/ & Public & & 4 year & A & B & $\$ 5,326.00$ & $\$ 7,420.00$ & 4,451 \\
\hline Glenville State College & 200 High Street & Glenville & www.glenville.edu/ & Public & & 4 year & A & B & $\$ 5,860.00$ & $\$ 8,810.00$ & 1,898 \\
\hline Huntington Junior College & 900 Fifth Avenue & Huntington & www.huntingtonjuniorcolle & EqPivate & for-profit & 2 year & A & & $\$ 7,485.00$ & none & 802 \\
\hline ITT Technical Institute - Huntington & 5183 US Route 60, Building & Huntington & www.itt-tech.edu & Private & for-profit & 2 year & A & & $\$ 18,048.00$ & none & 348 \\
\hline Kanawha Valley Community and Technical College & 2001 Union Carbide Drive & South Charleston & www.kvctc.edu & Public & & 2 year & A & & $\$ 3,236.00$ & none & 1,578 \\
\hline Marshall University & One John Marshall Drive & Huntington & www.marshall.edu/ & Public & & 4 year & A & B & $\$ 5,930.00$ & $\$ 8,988.00$ & 13,708 \\
\hline Mountain State College & 1508 Spring Street & Parkersburg & www.msc.edu & Private & for-profit & 2 year & A & & $\$ 8,215.00$ & none & 153 \\
\hline Mountwest Community and Technical College & One Mountwest Way & Huntington & www.mctc.edu & Public & & 2 year & A & & $\$ 2,952.00$ & none & 2,608 \\
\hline New River Community and Technical College & 221 George Street, Suite 2 & Beckley & www.newriver.edu & Public & & 2 year & A & & $\$ 3,234.00$ & none & 2,857 \\
\hline Ohio Valley University & 1 Campus View Drive & Vienna & www.ovu.edu & Private & & 4 year & A & B & $\$ 18,100.00$ & $\$ 6,676.00$ & 478 \\
\hline Pierpont Community and Technical College & 1201 Locust Avenue & Fairmont & www.pierpont.edu & Public & & 2 year & A & & $\$ 3,860.00$ & $\$ 7,420.00$ & 2,925 \\
\hline Potomac State College of WVU & 101 Fort Avenue & Keyser & www.potomacstatecollege. & EPublic & & 4 year & A & B & $\$ 3,178.00$ & $\$ 7,520.00$ & 1,781 \\
\hline Salem International University & 223 W. Main Street & Salem & www.salemu.edu & Private & for-profit & 4 year & A & B & $\$ 16,350.00$ & $\$ 6,400.00$ & 850 \\
\hline Shepherd University & PO Box 5000 & Shepherdstown & www.shepherd.edu/ & Public & & 4 year & & B & $\$ 5,834.00$ & $\$ 8,854.00$ & 4,326 \\
\hline Southern West Virginia Community and Technical & CPO Box 2900, 2900 Dempse & 'Mount Gay & www.southernwv.edu & Public & & 2 year & A & & $\$ 2,520.00$ & none & 2,178 \\
\hline Strayer University - West Virginia & 100 Corporate Center Dr & Scott Depot & www.strayer.edu/west-virgi & Private & for-profit & 4 year & A & B & $\$ 14,904.00$ & none & 220 \\
\hline University of Charleston & 2300 Maccorkle Avenue SE & Charleston & www.ucwv.edu & Private & & 4 year & A & B & $\$ 19,681.00$ & $\$ 9,000.00$ & 1,427 \\
\hline Valley College - Beckley & 120 New River Town Center & B Beckley & www.valley.edu & Private & for-profit & 2 year & A & & $\$ 16,025.00$ & none & 163 \\
\hline Valley College - Martinsburg & 287 Aikens Ctr Edwin Miller & r Martinsburg & $\underline{\text { www.valley.edu }}$ & Private & for-profit & 2 year & A & & $\$ 11,300.00$ & none & 77 \\
\hline West Liberty University & PO Box 295 & West Liberty & www.westliberty.edu/ & Public & & 4 year & A & B & $\$ 5,530.00$ & $\$ 8,200.00$ & 2,804 \\
\hline West Virginia Business College & 1052 Main Street & Wheeling & www.wvbc.edu & Private & for-profit & 2 year & A & & $\$ 9,150.00$ & none & 93 \\
\hline West Virginia Junior College - Bridgeport & 176 Thompson $\mathrm{Dr}$ & Bridgeport & www.wvjc.edu & Private & for-profit & 2 year & A & & $\$ 11,825.00$ & none & 229 \\
\hline West Virginia Junior College - Charleston & 1000 Virginia St E & Charleston & www.wvjc.edu & Private & for-profit & 2 year & A & & $\$ 11,800.00$ & none & 206 \\
\hline West Virginia Junior College - Morgantown & 148 Willey St & Morgantown & www.wvjc.edu & Private & for-profit & 2 year & A & & $\$ 13,152.00$ & none & 226 \\
\hline West Virginia Northern Community College & 1704 Market Street & Wheeling & www.wvncc.edu & Public & & 2 year & A & & $\$ 2,646.00$ & none & 2,505 \\
\hline West Virginia State University & PO Box 1000 & Institute & www.wvstateu.edu/ & Public & & 4 year & & B & $\$ 5,442.00$ & $\$ 6,698.00$ & 2,644 \\
\hline West Virginia University & PO Box 6201 & Morgantown & www.wvu.edu/ & Public & & 4 year & & B & $\$ 6,090.00$ & $\$ 8,508.00$ & 29,707 \\
\hline West Virginia Wesleyan College & 59 College Avenue & Buckhannon & www.wvwc.edu & Private & & 4 year & & B & $\$ 25,804.00$ & $\$ 7,510.00$ & 1,394 \\
\hline Wheeling Jesuit University & 316 Washington Avenue & Wheeling & www.wju.edu & Private & & 4 year & & B & $\$ 25,640.00$ & $\$ 9,028.00$ & 1,549 \\
\hline WVU Institute of Technology & 405 Fayette Pike & Montgomery & www.wvutech.edu/ & Public & & 4 year & & B & $\$ 5,558.00$ & $\$ 8,176.00$ & 1,107 \\
\hline WVU Parkersburg & 300 Campus Drive & Parkersburg & www.wvup.edu & Public & & 4 year & A & B & $\$ 2,496.00$ & none & 3,824 \\
\hline
\end{tabular}


By providing a decision-making process that allowed students to quickly filter schools in stages based on a small selection of criteria, the project minimizes the "cognitive burden" that forty-one options would otherwise create. In order to determine what these filters should be to best serve the students, three design methods were initially used to gauge the thoughts, perceptions, and desires of the target audience.

Survey. A self-completed questionnaire was administered to fifty-five eleventh grade students at Gilmer County High School (figure 4).

Focus Group. Drawn from the same population of students who were surveyed, twenty eleventh grade students also participated in a follow-up focus group to provide additional insight into the level of understanding students have concerning the college search and application process.

Card Sort. The twenty students in the focus group were partnered up to complete a card sort. Students were asked to sort the cards that contained ten different criteria that could be used to determine interest in a college, from most important (\#1) to least important (\#10) (table 2).

From these three methods, many important insights were gained that guided the creation of the final product. For example, the questionnaire revealed that students consider major, cost, and a school's distance from home to be very important factors when choosing a college (\#2). While qualitative feedback from the focus group revealed that many students start their search using Google or a similar search engine, the questionnaire indicates that many students start their search using the websites of individual schools (\#3). And while the questionnaire illustrates that most of the students seemed to have a good understanding of when selected preparatory tasks should take place (\#4), discussion in the focus group revealed their desire for a more clearly defined timeline, particularly a starting point. 
Figure 4. Survey administered to Gilmer County High School juniors with recorded responses.

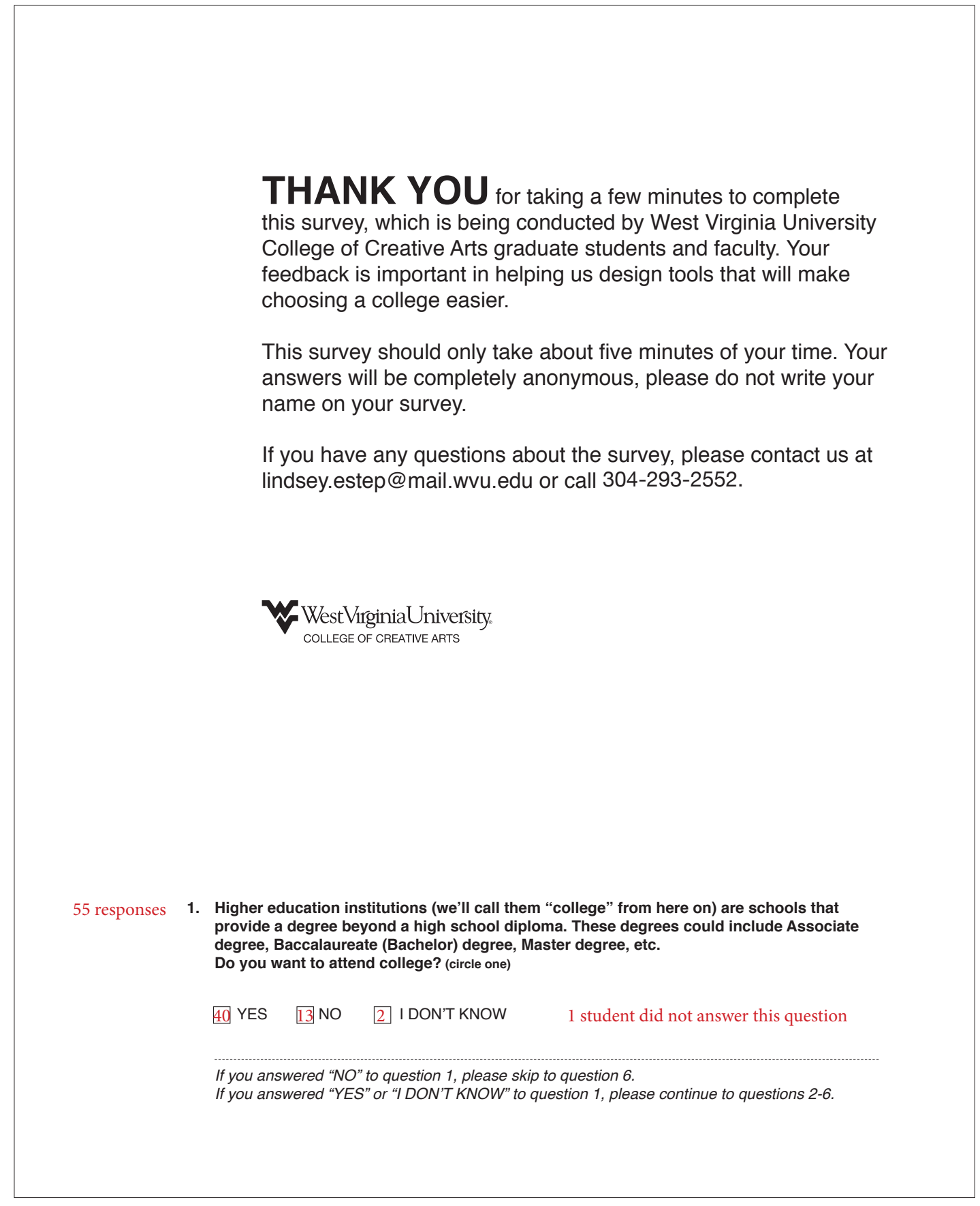


Figure 4. (continued)

55 responses 2. How important are each of the items below when choosing which college you want to attend?

A college that has my desired major

Cost of tuition and room and board charges

Physical size or layout of the college's campus

Number of students that attend the college

Number of activities, clubs, or sports available to participate in

College's distance from my home

Having a friend or family

member who attends/attended

Other

\begin{tabular}{|c|c|c|}
\hline $\begin{array}{c}\text { Not } \\
\text { Important }\end{array}$ & $\begin{array}{c}\text { Somewhat } \\
\text { Important }\end{array}$ & $\begin{array}{c}\text { Very } \\
\text { Important }\end{array}$ \\
\hline & 3 & 40 \\
\hline 13 & 18 & 25 \\
\hline 18 & 18 & 8 \\
\hline 15 & 22 & 6 \\
\hline 9 & 16 & 18 \\
\hline 22 & 20 & 1 \\
\hline & & \\
\hline
\end{tabular}

29 responses 3 . When preparing to research a college that you may wish to attend, which of these sources are you likely to seek FIRST? (check one)

\begin{tabular}{|c|l|}
\hline 8 & School Counselor \\
\hline 2 & Teacher \\
\hline 4 & Parents \\
\hline & Siblings/Cousins \\
\hline 1 & Friends \\
\hline 11 & $\begin{array}{l}\text { College websites (like www.wvu.edu } \\
\text { or www.glenville.edu, etc) }\end{array}$ \\
\hline & $\begin{array}{l}\text { Other websites (like US News \& } \\
\text { World Report, www.cfwv.com, etc.) }\end{array}$ \\
\hline 3 & Mail that you receive directly from colleges \\
\hline & Other_ \\
\hline
\end{tabular}

42 responses 4 . When do you believe each of the following college preparatory tasks should take place?

ACT/SAT tests

Applying to college(s)

Visiting college campuses

Speaking with a college's admissions counselor

Completing the FAFSA

(Free Application for Federal Student Aid)

Applying for scholarships

Creating a list of colleges you may be interested in

\begin{tabular}{|c|c|c|}
\hline $\begin{array}{c}\text { JUNIOR } \\
\text { YEAR }\end{array}$ & $\begin{array}{c}\text { SENIOR } \\
\text { YEAR }\end{array}$ & $\begin{array}{c}\text { Not } \\
\text { Sure }\end{array}$ \\
\hline 31 & 7 & 2 \\
\hline 9 & 32 & 1 \\
\hline 22 & 17 & 3 \\
\hline 5 & 31 & 5 \\
\hline 7 & 30 & 5 \\
\hline 8 & 31 & 3 \\
\hline 35 & 2 & 3 \\
\hline
\end{tabular}


Figure 4. (continued)

40 responses 5. How likely are you to seek the opinions of friends and family members through the following social media platforms when comparing colleges?

Instagram

Facebook

Twitter

SnapChat

Tumblr

Vine

Pheed

Pinterest

Google+

Other Google

\begin{tabular}{|c|c|c|}
\hline $\begin{array}{c}\text { NOT } \\
\text { LIKELY }\end{array}$ & LIKELY & $\begin{array}{c}\text { VERY } \\
\text { LIKELY }\end{array}$ \\
\hline 31 & 8 & 1 \\
\hline 9 & 22 & 9 \\
\hline 22 & 14 & 4 \\
\hline 29 & 6 & 5 \\
\hline 35 & 5 & \\
\hline 34 & 6 & \\
\hline 33 & 7 & 2 \\
\hline 31 & 7 & 3 \\
\hline 26 & 11 & \\
\hline & 1 & \\
\hline
\end{tabular}

6. Please circle your gender.

24 MALE 30 FEMALE 2 students did not respond to this question

11 responses 7. If you answered "NO" to question 1, indicate how you feel about the following reasons to not attend college?

I cannot afford to attend

I want to start making money now by getting a job I don't feel smart enough to attend

I don't know what I want to study

My parents don't want me to attend

I only need certain skills, not a degree

Choosing and applying to a school is too much work or too confusing

Other_military

\begin{tabular}{|c|c|c|c|c|}
\hline $\begin{array}{c}\text { STRONGLY } \\
\text { DISAGREE }\end{array}$ & DISAGREE & NEUTRAL & AGREE & $\begin{array}{c}\text { STRONGLY } \\
\text { AGREE }\end{array}$ \\
\hline 3 & 3 & 3 & 1 & 1 \\
\hline 1 & & 2 & 2 & 6 \\
\hline 4 & 2 & 3 & 1 & 1 \\
\hline 4 & 4 & & 1 & 2 \\
\hline 6 & & 1 & 4 & 2 \\
\hline 4 & & 2 & 2 & 1 \\
\hline 6 & & & & \\
\hline
\end{tabular}


Table 2. Card sort results. Ten sets of partners ranked decision-making criteria from \#1 most important to \#10 least important.

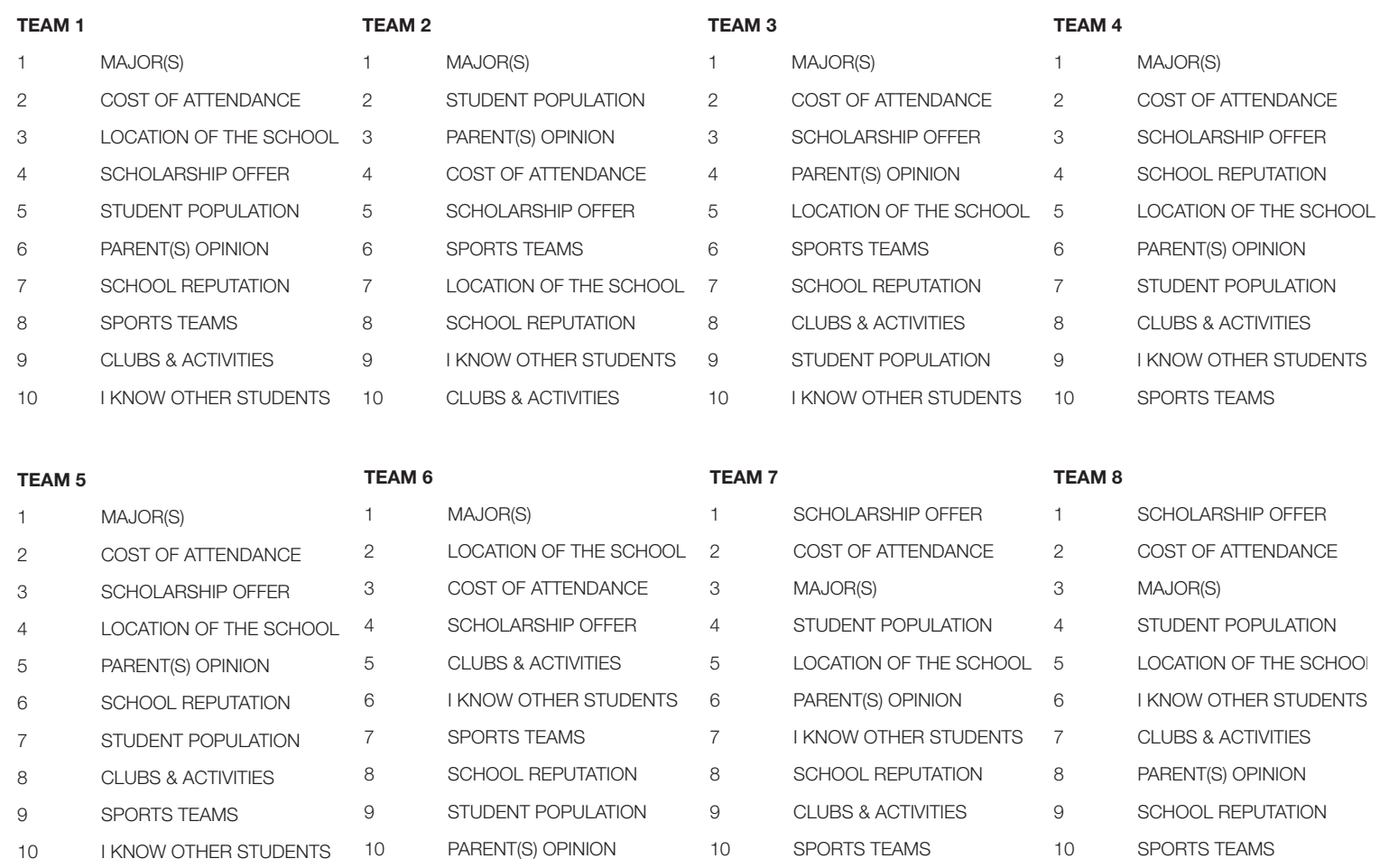

\begin{tabular}{llll} 
TEAM 9 & \multicolumn{3}{l}{ TEAM 10} \\
1 & SCHOLARSHIP OFFER & 1 & SPORTS TEAMS \\
2 & MAJOR(S) & 2 & COST OF ATTENDANCE \\
3 & COST OF ATTENDANCE & 3 & MAJOR(S) \\
4 & LOCATION OF THE SCHOOL & 4 & PARENT(S) OPINIONS \\
5 & STUDENT POPULATION & 5 & SCHOLARSHIP OFFER \\
6 & SCHOOL REPUTATION & 6 & LOCATION OF THE SCHOOL \\
7 & PARENT(S) OPINION & 7 & STUDENT POPULATION \\
8 & I KNOW OTHER STUDENTS & 8 & SCHOOL REPUTATION \\
9 & CLUBS \& ACTIVITIES & 9 & CLUBS \& ACTIVITIES \\
10 & SPORTS TEAMS & 10 & I KNOW OTHER STUDENTS
\end{tabular}

$\begin{array}{llll}\text { TOTALS } & & & \\ 17 & \text { MAJORS } & 59 & \text { PARENT(S) OPINION } \\ 24 & \text { COST OF ATTENDANCE } & 71 & \text { SCHOOL REPUTATION } \\ 30 & \text { SCHOLARSHIP OFFER } & 77 & \text { SPORTS TEAMS } \\ 46 & \text { LOCATION OF THE SCHOOL } & 82 & \text { CLUBS \& ACTIVITIES } \\ 59 & \text { STUDENT POPULATION } & 85 & \text { I KNOW OTHER STUDENTS }\end{array}$

RESULTS

Criteria with the lowest scores are most important to students. 
In early stages of the project, an idea surfaced to provide students with prompts to interact and share their search process through social media as a way to collect input and encouragement from friends, family, and potentially, alumni from the schools that the student was considering. It is no secret that teenagers widely use social media as a way of documenting their experiences, and many articles claim that teens are gravitating away from Facebook and towards Instagram and Twitter to do this sharing. (Madden 2013) The questionnaire administered to the Gilmer County High School students however, did not necessarily support these claims, and did not indicate that teens would be willing to share an experience like trying to select a college through social media channels. Further questioning in the focus group found that, while students were open to the idea of sharing positive reports (e.g. winning a scholarship, being accepted to a desired school, or making a final decision as to which school to attend), the majority of students expressed a distaste for taking to social media to openly ask for opinions.

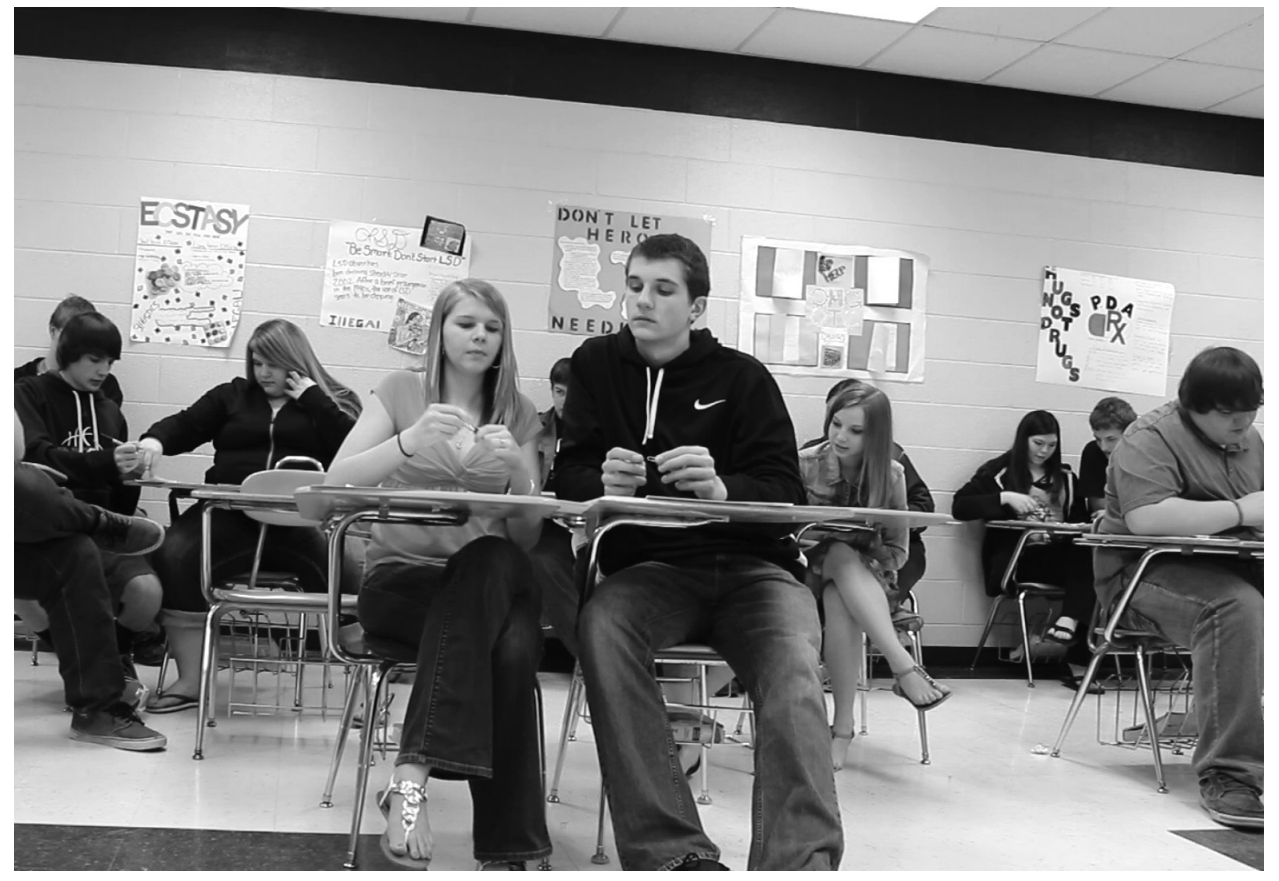

Students complete the college selection criteria card sort activity. 


\section{DESCRIBING THE CHOICE OPTIONS}

In order to embrace the role of choice architect, it is not enough to simply gather the information to present to decision makers. Great care must be exercised to ensure that the information is presented in a way that those decision makers-particularly those in the greatest need for guidance-can draw insight from in order to reach the solution that will be most beneficial to their future. This is what Johnson et al considered the second set of tools available to choice architects, and also where designers have the greatest ability to guide the decision makers along the path of complex determinations like which college to attend.

Because the college selection process is at least somewhat dependent on and intertwined with the college application process, it is not sufficient to present only standardized data about the forty-one institutions in West Virginia and expect students to make a choice that leads to a better outcome than the one they would have made on their own. To that end, it was decided that presenting the decision-making criteria within the context of a guide for the entire application process would best meet students' needs. In addition to the comparison information, the guide would highlight important resources and deadlines across the board in order to maximize students' chances of completing necessary tasks on-time, leading to better financial aid and placement opportunities in the college of their choice.

The final format chosen was a mini-folder that contained a guide booklet in one pocket and a series of cards containing infographics of the decisionmaking criteria in the other pocket. This format allows for a reader-driven experience where the student can use the tools in a non-linear fashion based on where they are in their individual search or decision process, or based on the criteria they feel more strongly about. The project was titled "DIY Guide to the Epic College Decision: Find your own path through the WV college 
search and application process!" The infographic tools for decision-making were chosen based on student responses from the survey and focus group discussion: location and size, cost, type of degree offered, and majors. (See Appendix A for images of the booklet and cards.)

Most important to the decision of how to present the data was ensuring that students could compare schools side-by-side on equal scales and in terms that were understandable and relatable to the audience. This decision is in the spirit of Thaler and Sunstein's RECAP: Record, Evaluate, and Compare Alternative Prices model of disclosure and transparency (Thaler 2009). One of the first major decisions in describing the choice options was to categorize the colleges based on whether they were privately funded or publicly funded, and based on what type of degree, Associate or Baccalaureate, they awarded (although there was some overlap in four year schools that also award a select number of Associate degrees). These distinctions were important in helping to illustrate the value proposition (what one gets vs. what one pays) to students, particularly to disadvantaged students. Johnson discusses this partitioning of the choice options and confirms, "partitioning will tend to exert the strongest paternalistic influence on those who need the greatest guidance and will have the weakest effect on those who require the least guidance." (Johnson 2013)

In addition to partitioning the data, each of the decision-making tools utilizes narrative elements to guide the viewer through the data while also addressing important outliers and relationships. While some elements of a story are provided as an introduction into the data for each individual tool, the visualizations are still created in a way to allow for self-discovery and exploration. They are not, however, without subtle nudges from the designer. In their research of visual narratives, authors Edward Segel and Jeffrey Heer explore the ways that one might direct a viewer's attention: 
Of course, not all elements in a scene are of equal importance

throughout a story, and so authors often manipulate a scene to direct attention to a point of interest. Psychologists have extensively studied phenomena of visual salience, showing that outliers among visual features such as color, size, and orientation preferentially attract one's attention. (Segel 2010)

In some cases this attention may need to be minimized. For example, in the location and size data visualization (figure 5), students will likely recognize that American Public University Systems is the largest institution in the state, by several thousand students no less. What is not readily obvious from the data set, is that the school delivers a strictly online education and, while they do maintain a physical campus, APUS does not have a traditional campus or university setting. A special callout was included to bring this information to students' attention and minimize the perceived size of the school before making a decision about that particular school. In contrast, a special callout was created on the tuition price graphic (figure 6) to maximize a relationship that students may not immediately perceive. The bar graph illustrates that the majority of West Virginia's four-year public institutions charge tuition that differs by $\$ 1,000$ per year or less. The annotation highlights this fact so that students considering those schools will be discouraged from making a decision based mainly on price, but would instead look to other factors or indicators of quality. 
Figure 5. Location and size infographic decision-making tool.

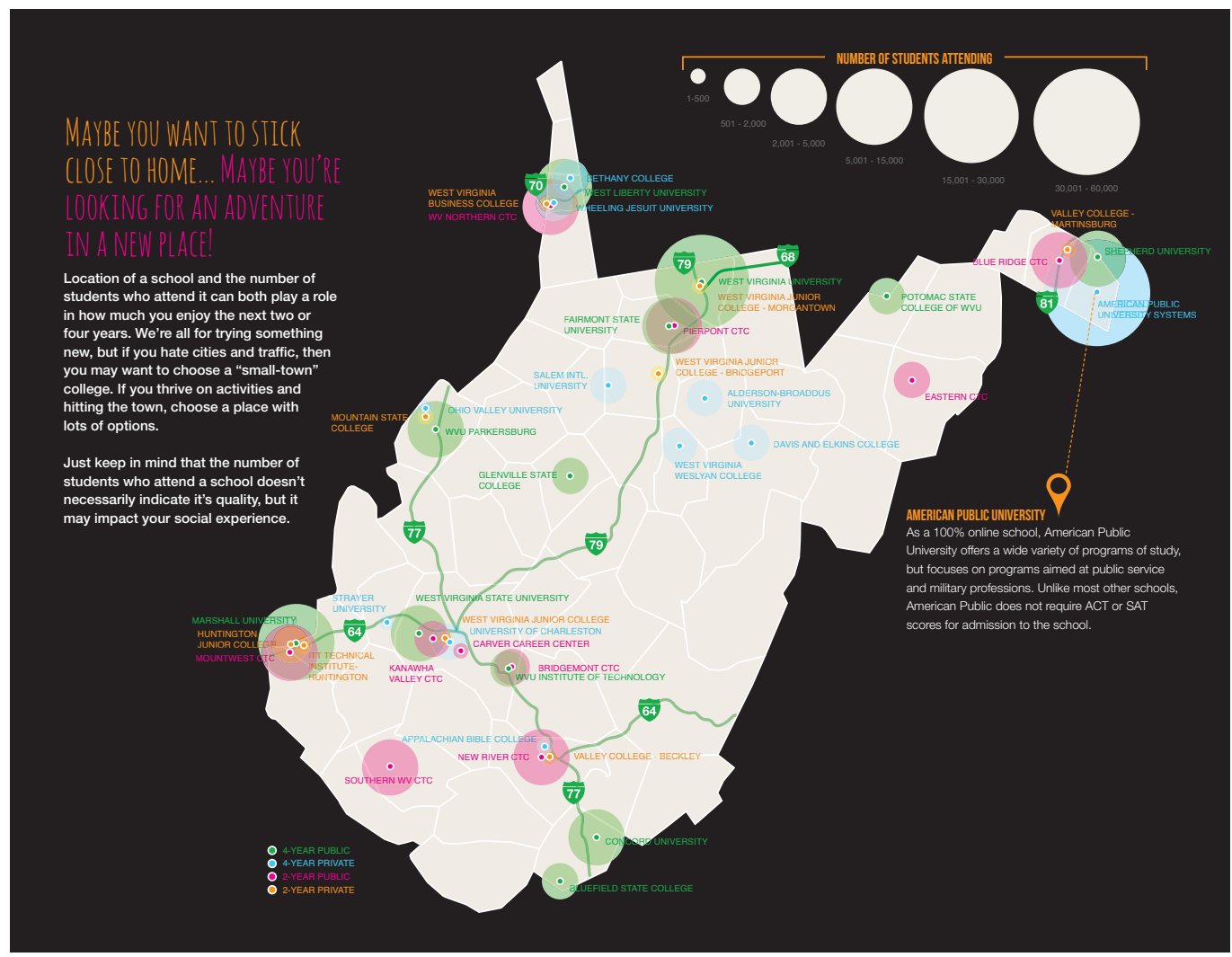

Figure 6. Cost infographic decision-making tool.

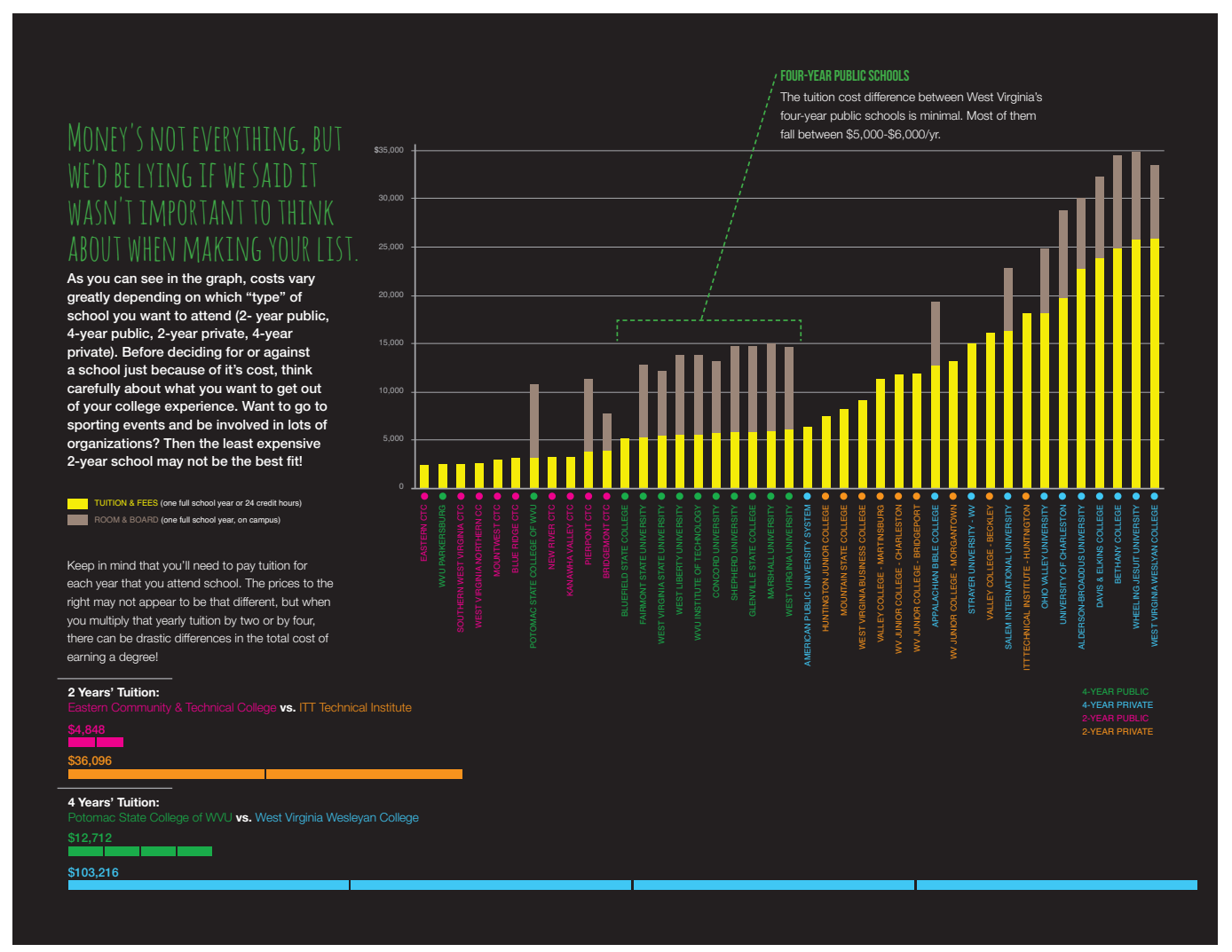




\section{GOING BACK TO HIGH SCHOOL}

To be certain that the college decision data being presented was

understandable to the target audience, the group of twenty eleventh grade students who were part of the focus group also participated in A/B testing-a tool used to optimize designs to generate a desired response from an audience-for one of the data visualization designs. Students were presented two different designs (figure 7) representing the same information and then asked to complete tasks to ensure they had the capability to extract relevant information from the graphic.
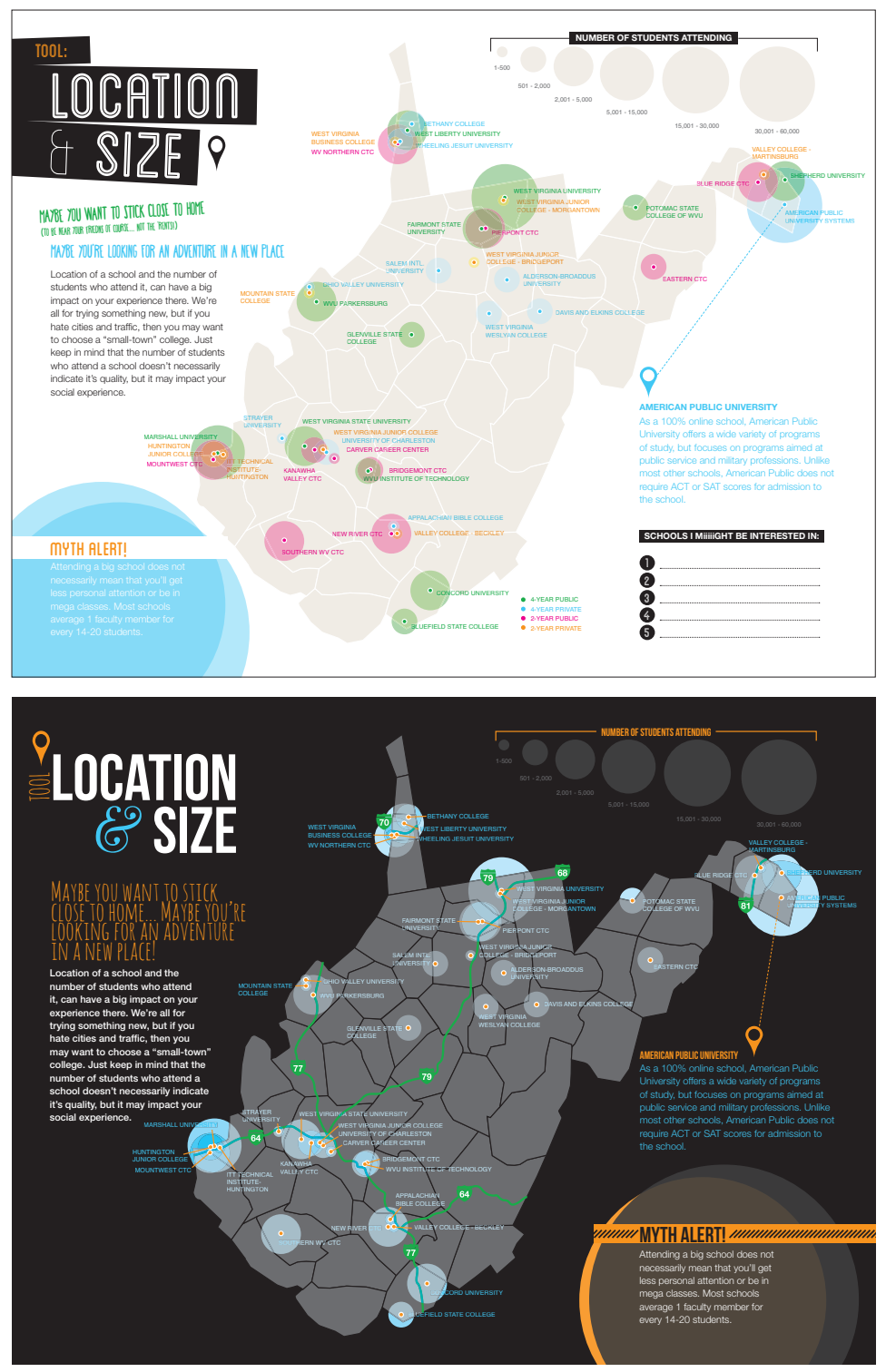
Each student was also given a follow-up questionnaire to provide qualitative feedback about each design (figure 8). This feedback was then adapted and applied to the other graphic tools contained within the project.

\section{GILMER COUNTY HIGH SCHOOL FOCUS GROUP DESIGN SURVEY

1. Look at the white design. If you were interested in going to a public, four-year college that had $\mathbf{2 , 0 0 0}$ students or less, what would be one of your options? (Hint: there are four options that meet that criteria, just list one.)

One student (out of 21) answered incorrectly.

2. Using the black design, list the three colleges that have the largest number of students in WV. (list in any order)

1

3-

One student (out of 21) answered incorrectly.

3. Is one map easier to understand? If so, which map is easier, and why?

WHITE - 14 votes Students seemed to prefer the color coding and having the additional BLACK - 5 votes information about school types. Some commented that the black map was NEITHER - 2 votes easier to read, and liked having the major routes shown.

4. If you were searching for a college right now, how helpful is it to be able to compare the following criteria about each college in West Virginia

\begin{tabular}{|c|c|c|c|c|}
\cline { 2 - 5 } & $\begin{array}{c}\text { Not } \\
\text { Helpful }\end{array}$ & Neutral & $\begin{array}{c}\text { Somewhat } \\
\text { Helpful }\end{array}$ & $\begin{array}{c}\text { Very } \\
\text { Helpful }\end{array}$ \\
\cline { 2 - 5 } where colleges are located in the state & & 1 & 8 & 12 \\
\cline { 2 - 5 } number of students that attend each college & & 2 & 8 & 11 \\
\cline { 2 - 5 } whether a college is public or private & & 2 & 5 & 14 \\
\cline { 2 - 5 } whether a college is 2-year or 4-year & & 2 & 4 & 14 \\
\cline { 2 - 5 } & & &
\end{tabular}

5. If the design had a place fo you to make personal notes or write down schools you were interested in (similar to the block in the lower right corner of the white design), how likely would you be to fill in that area? 2 NOT LIKELY 4 NEUTRAL 13 SOMEWHAT LIKELY 2 VERY LIKELY

6. Based only on looks, do you prefer the white design or the black design? Why? WHITE - 16 votes BLACK - 15 votes

7. If this map tool was combined with other tools and information designed to help you compare schools an make your college decision easier, which title and tagline do you think we should use for the project?

7 College Insta-Compare: Your total guide to comparing WV colleges, surviving the application process, and Instagramming the whole experience!

3 College Compare Fair: Forget the free pens and bubbly admissions counselor. This DIY "College Fair" has the info you really need to choose a WV college and survive the application process!

12 DIY Guide to the Epic College Decision: Find your own path through the WV college selection and application process!

THANK YOU for participating! We'd love to hear your thoughts. If you would like to provide any additional comments about either design, please do so on the back of this sheet.

"I like that the black one includes the interstates. I think it makes it easier to visualize the location."

Figure 8. Questionnaire that accompanied the A/B test images, and the tallied results of that questionnaire. 
Teenagers are a highly discriminating audience. With companies vying for their attention daily through both print and digital media, landing on a look and tone for the final project where equal consideration was given to information to present and how best to present it was critical. A childish tone would make the project fodder for ridicule, while a look or tone too stiff and formal could be perceived as advertising or paternalism. Either way, it would be impossible for the project to achieve its goal without finding the appropriate middle ground. An extensive survey conducted by Piper Jaffray into the habits and preferences of teens pointed to the brands and companies that teenagers are most attracted to and trends that are taking shape among teen buyers (Piper Jaffray 2013).

After visiting the respective websites and looking at advertising for many of the popular brands, aesthetic and tonal preferences were deduced and then adapted for the final writing and design of this project. Common design themes among those desired brands included: use of bold sans serif typefaces; frequent use of hand rendered typefaces; combinations of bright, highly saturated colors; use of bold geometric objects; and use of a casual tone that remained gender-neutral (figure 9). In addition to these considerations, the inclusions of other common experiences in the life of a teenager (e.g. writing a junior research paper, escaping one's parents, anticipating junior prom) were placed throughout the narrative to keep the content relatable and engaging.

A final consideration in how best to present this visual narrative to a teenage audience was the production vehicle or medium. Although an interactive website or application could have allowed for more powerful discoveries in the data by the students themselves, those media could also potentially introduce a barrier to entry for disadvantaged students or those with limited access to high-speed internet. It was important that every single student have easy access, in the environment of their choosing, to read and study the content of the project. It is hoped that the physical presence of the materials 
will be a more ready reminder and prompt than a virtual environment would provide. In order to introduce an element of interactivity in an analog medium such as print, students are provided with prompts to begin building their list of potential schools as they use the decision-making tools. The creation of multiple short lists over the course of the project allows the student to see regularities among their schools of interest in order to better inform their final decision.

Figure 9. Websites and advertisements from teens favorite brands, and layouts from popular magazines that inspired many of the design choices for this project.

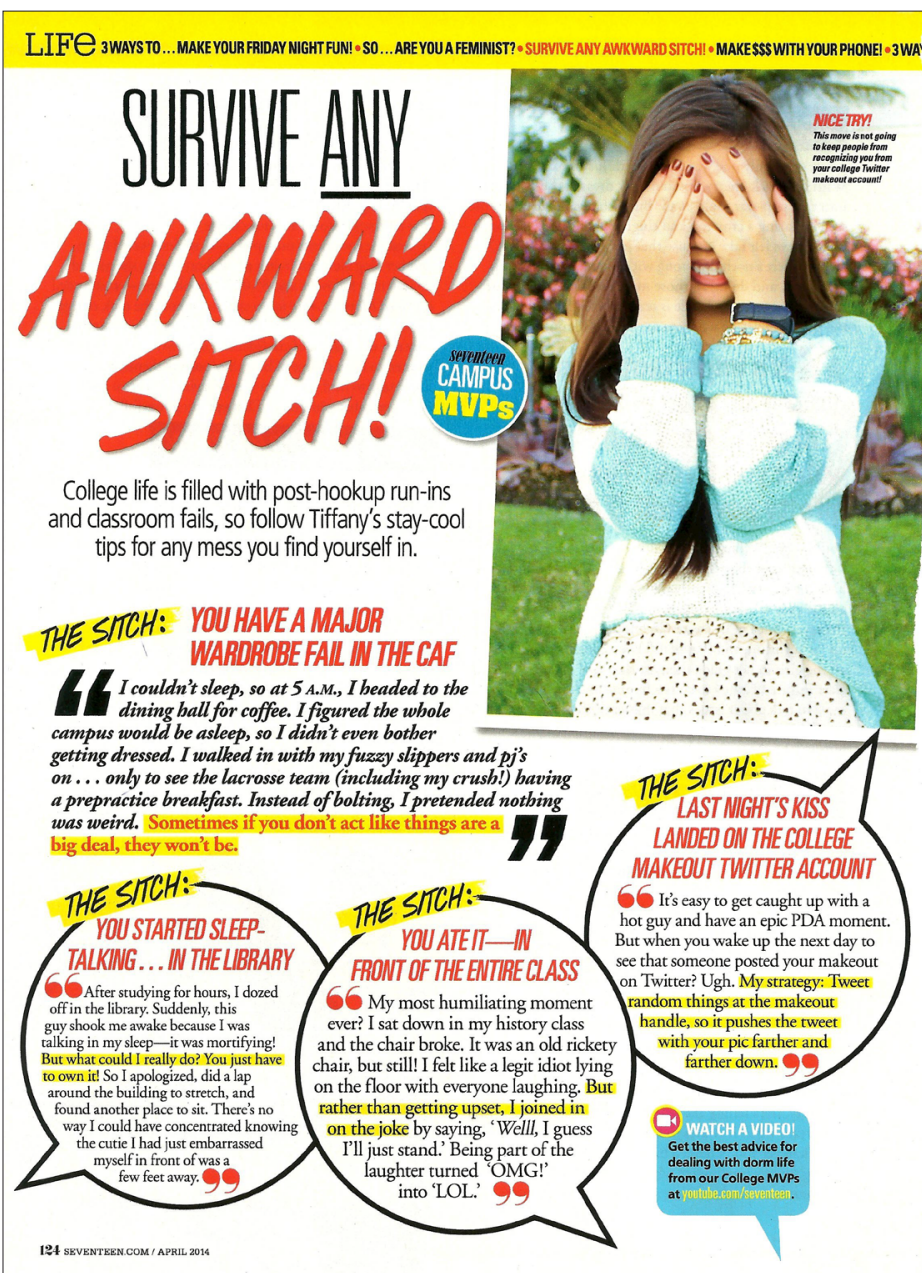

Magazine page from Seventeen April 2014. Inspiration: tone, hand-rendered typography

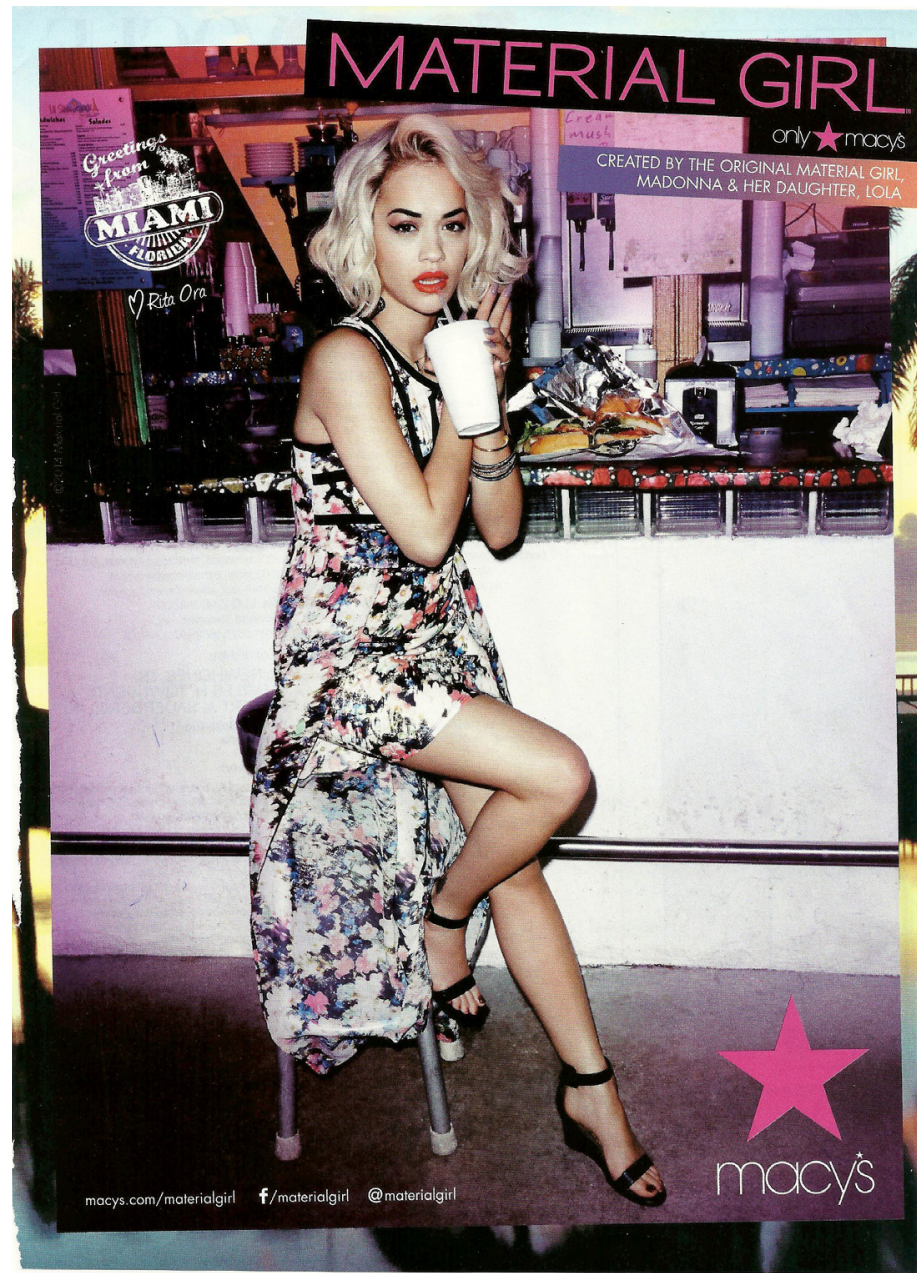

Macy's advertisement from Teen Vogue April 2014. Inspiration: black with bright color, geometric elements 
Figure 9. (continued)

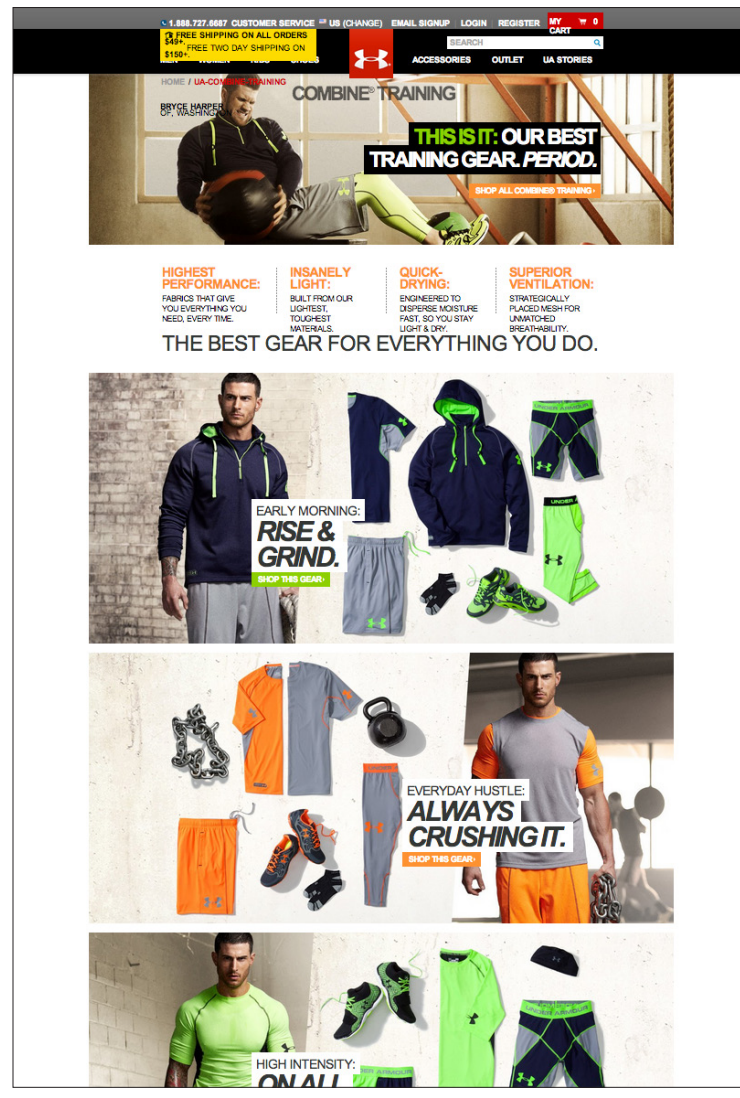

Screenshot from www.underarmour.com, April 2014. Inspiration: bright, saturated colors, bold sans serif type

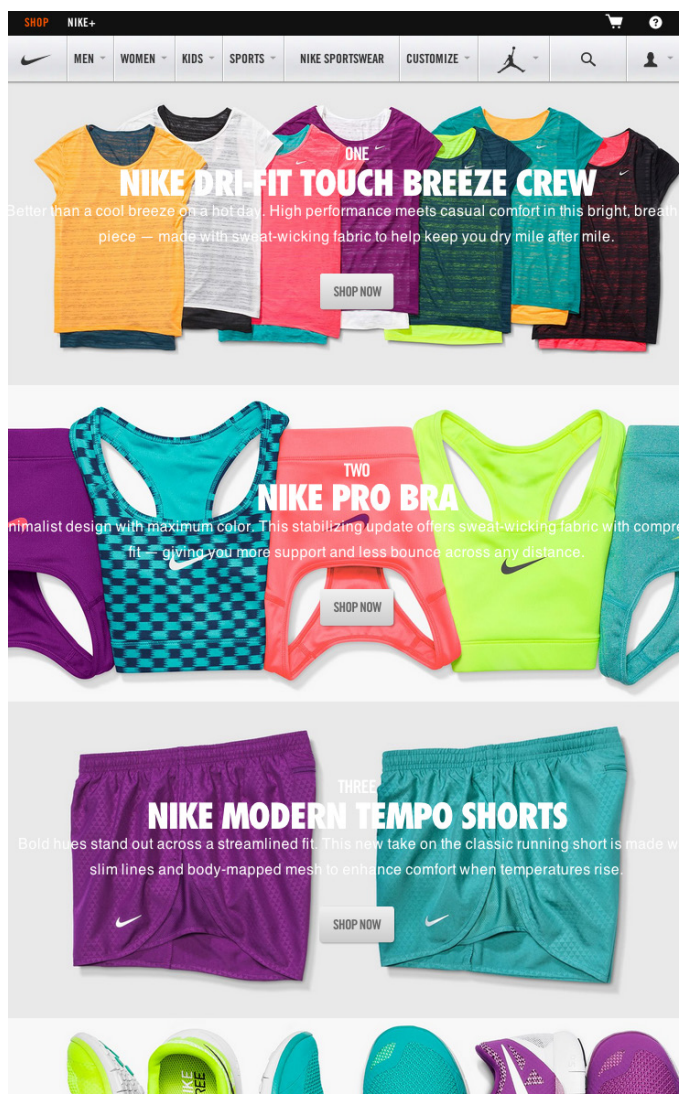

Screenshot from www.nike.com, April 2014.

Inspiration: bright, saturated colors, bold sans serif type

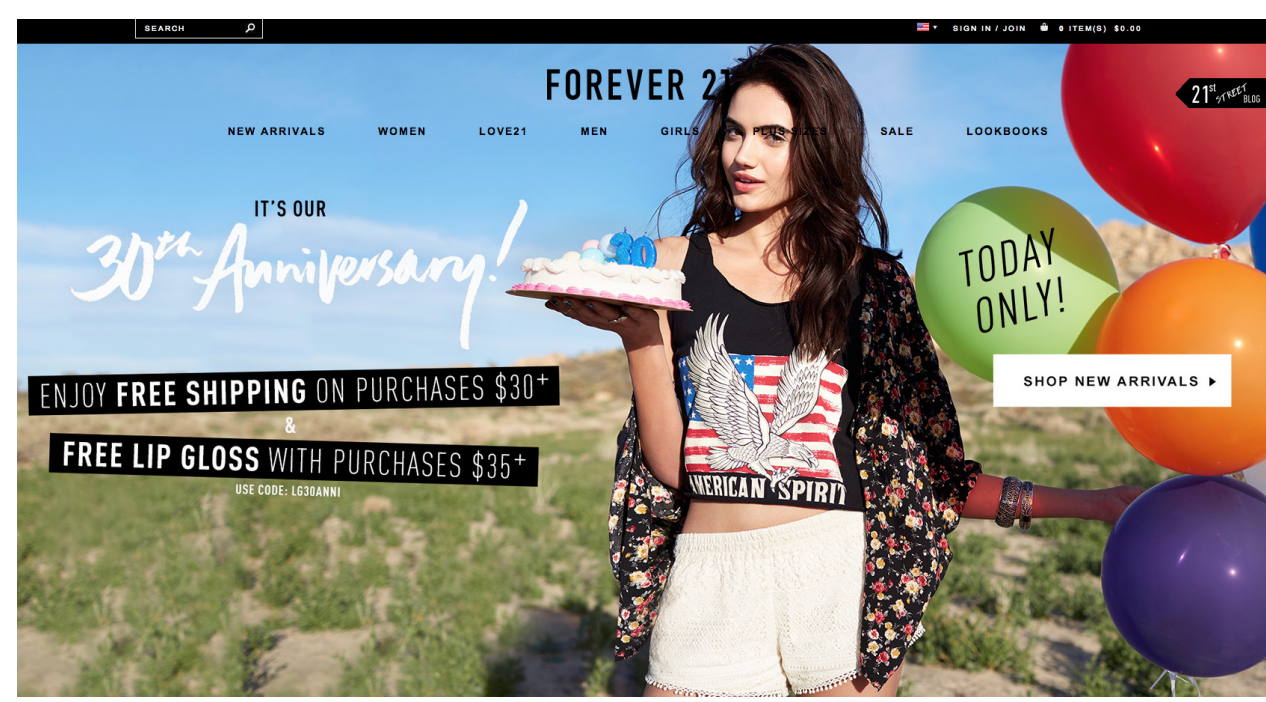

Screenshot from www.forever21.com, April 2014.

Inspiration: black with bright color, geometric elements, hand-rendered typography 


\section{CONCLUSION}

By converting college search decision-making data that students are most concerned with-such as cost of attendance, size and enrollment, and majorsinto infographics, and then framing the decision with a narrative and gentle nudges, the DIY Guide to the Epic College Decision has restructured the information architecture of a major decision faced by teenagers. The project brings together scattered pieces of data into a central location which allows for direct comparison of all undergraduate degree-granting college options to convert that data to information. By providing context for that information in a visual and verbal format that students relate, the project helps students convert that information into knowledge. Ultimately, students are escorted through the knowledge pyramid in order to gain wisdom to make a decision that will most beneficial to their future. Renowned design strategist Nathan Shedroff explains the value of each stage of this continuum (figure 10):

Data is fairly worthless to most of us; it is the product of research or creation (such as writing), but it is not an adequate product for communicating. To have information value, it must be organized, transformed, and presented in a way that gives it meaning. Information is also not the end of the continuum of understanding. Just as data can be transformed into meaningful information, so can information be transformed into knowledge and, further, into wisdom. Knowledge is a phenomenon that we can build for others just as we can build information for others from data. This is done through Interaction Design and the creation of experiences. [...] We should always make [knowledge] our goal because it allows the most valuable messages to be conveyed. It is also the last level that we can directly effect[.] (Shedroff 1994) 


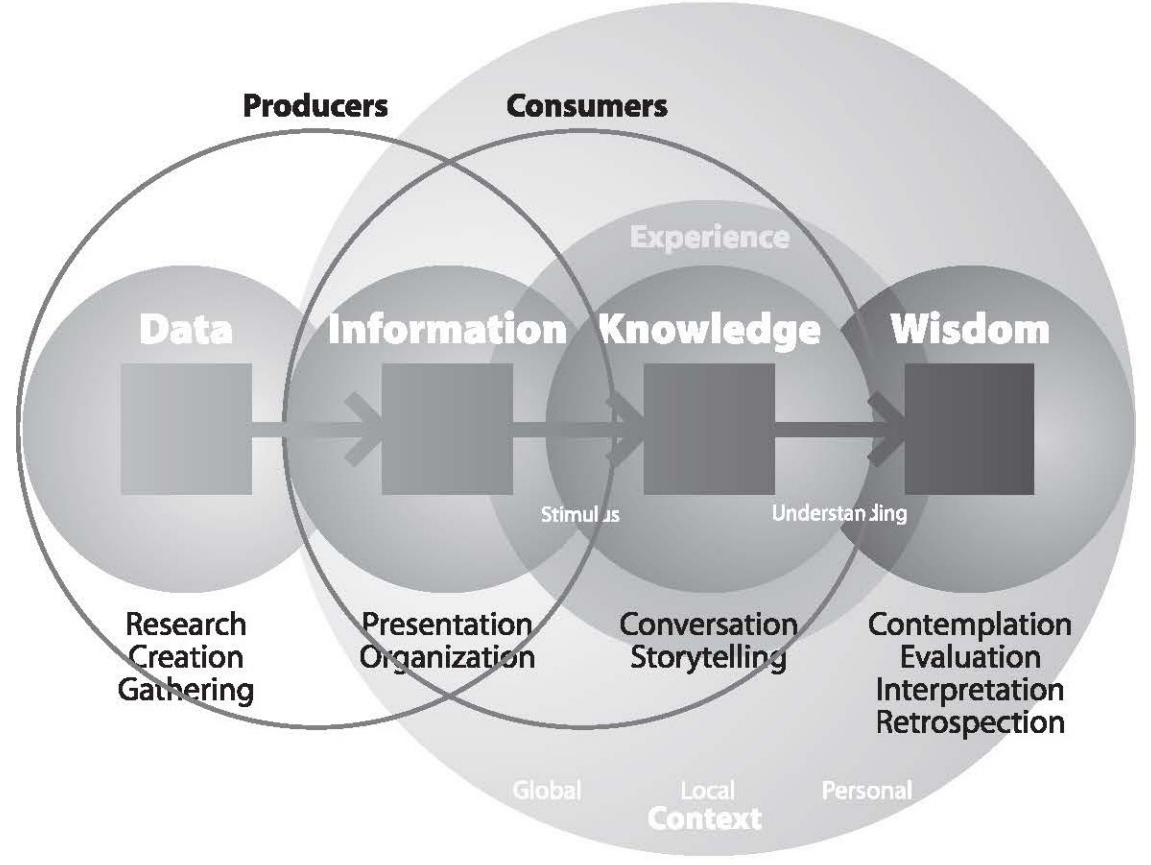

Figure 10. An annotated Data, Information, Knowledge, Wisdom (DIKW) continuum by Nathan Shedroff. (Shedroff 1994).

Prior to this project, West Virginia students could certainly find and gather data about the forty-one degree-granting institutions and could even organize it into information if willing to invest the time and cognitive effort. By completing these two stages thoroughly and then creating knowledge by wrapping that information in context, the DIY Guide to the Epic College Decision has provided a nudge-all while preserving freedom of choicetowards a wise decision. 
The result of this redesigned choice architecture will be that students can more effectively navigate the West Virginia college search and application process and end up in colleges best suited to their needs. This reduced complexity opens the door for more students to make the transition from high school to college (the current college-going rate in Gilmer County where data for this project was collected is 53\%)(West Virginia Higher Education Policy Commission 2014), which could provide long-ranging socio-economic impacts to the state through a better-educated workforce and a reduction in the percentage of residents living below the poverty level due to increased educational attainment.

Extensions of this research into other areas of teenage life could include providing nudges to teens in less systematic decisions they face such as nudging young drivers to form safe habits, encouraging the recognition and pursuit of healthy relationships, or inspiring impressionable young adults to avoid drugs or alcohol. These decisions have much less natural structure built around them and less defined and finite choice possibilities like the timelines and options associated with selecting and applying to a college. Creating better choice architecture in all areas of the lives of teens could have equally positive social and economic affects for West Virginia. 


\section{BIBLIOGRAPHY}

Bishaw, Alemayehu. "Poverty: 2010 and 2011. American Community Survey Briefs." 2012. http://www.census.gov/prod/2012pubs/acsbr11-01.pdf (accessed April 22, 2014).

Johnson, Eric J. and Shu, Suzzane B. and Dellaert, Benedict G. C. and Fox, Craig R. and Goldstein, Daniel G. and Haeubl, Gerald and Larrick, Richard P. and Payne, John W. and Peters, Ellen and Schkade, David and Wansink, Brian and Weber, Elke U. "Beyond Nudges: Tools of a Choice Architecture." Marketing Letters. June 2013. http://papers. ssrn.com/sol3/papers.cfm?abstract_id=2277968 (accessed April 18, 2014).

Madden, Mary and Lenhart, Amanda and Cortesi, Sandra and Gasser, Urs and Duggan, Maeve and Smith, Aaron and Beaton, Meredith. "Teens, Social Media, and Privacy." May 21, 2013. http://www.pewinternet.org/2013/05/21/teens-social-media-andprivacy/ (accessed April 3, 2014).

Martin, Bella and Hanington, Bruce. Universal Methods of Design. Beverly, MA: Rockport, 2012.

National Center for Higher Education Management Systems. "NCHEMS Information Center for Higher Education Policymaking and Analysis." 2011. http://www.higheredinfo.org/stateprofile/index. php?years $=$ DEFAULT $\&$ measures $=$ DEFAULT $\&$ columns $=$ DEFAULT $\&$ state $=54$ (accessed March 23, 2014).

Piper Jaffray \& Co. “Taking Stock with Teens: Results Presentation.” April 2013. http:// www.whiteboardadvisors.com/files/Taking_Stock_Teach-in_Spring_2013_MV_2.pdf (accessed March 23, 2014). 
Segel, Edward and Heer, Jeffrey. "Narrative Visualization: Telling Stories with Data." Visualization and Computer Graphics. November - December 2010. http://ieeexplore.ieee.org.www.libproxy.wvu.edu/stamp/stamp. jsp?tp=\&arnumber $=5613452$ (accessed April 18, 2014).

Shedroff, Nathan. "Information Interaction Design: A Unified Field Theory of Design." 1994. http://www.nathan.com/thoughts/unified/ (accessed April 18, 2014).

Thaler, Richard H. and Sunstein, Cass R. Nudge: Improving Decisions About Health, Wealth, and Happiness. New York: Penguin, 2009.

U.S. Department of Education Institute of Education Sciences National Center for Education Statistics. “College Navigator." 2014. https://nces.ed.gov/ collegenavigator/ (accessed March 23, 2014).

West Virginia Higher Education Policy Commission. "West Virginia College Going Rates By County and High School Fall 2012.” 2014. http://www. wvhepc.com/wp-content/uploads/2014/01/cgr_2012.pdf (accessed March 23, 2014). 


\section{APPENDIX A}

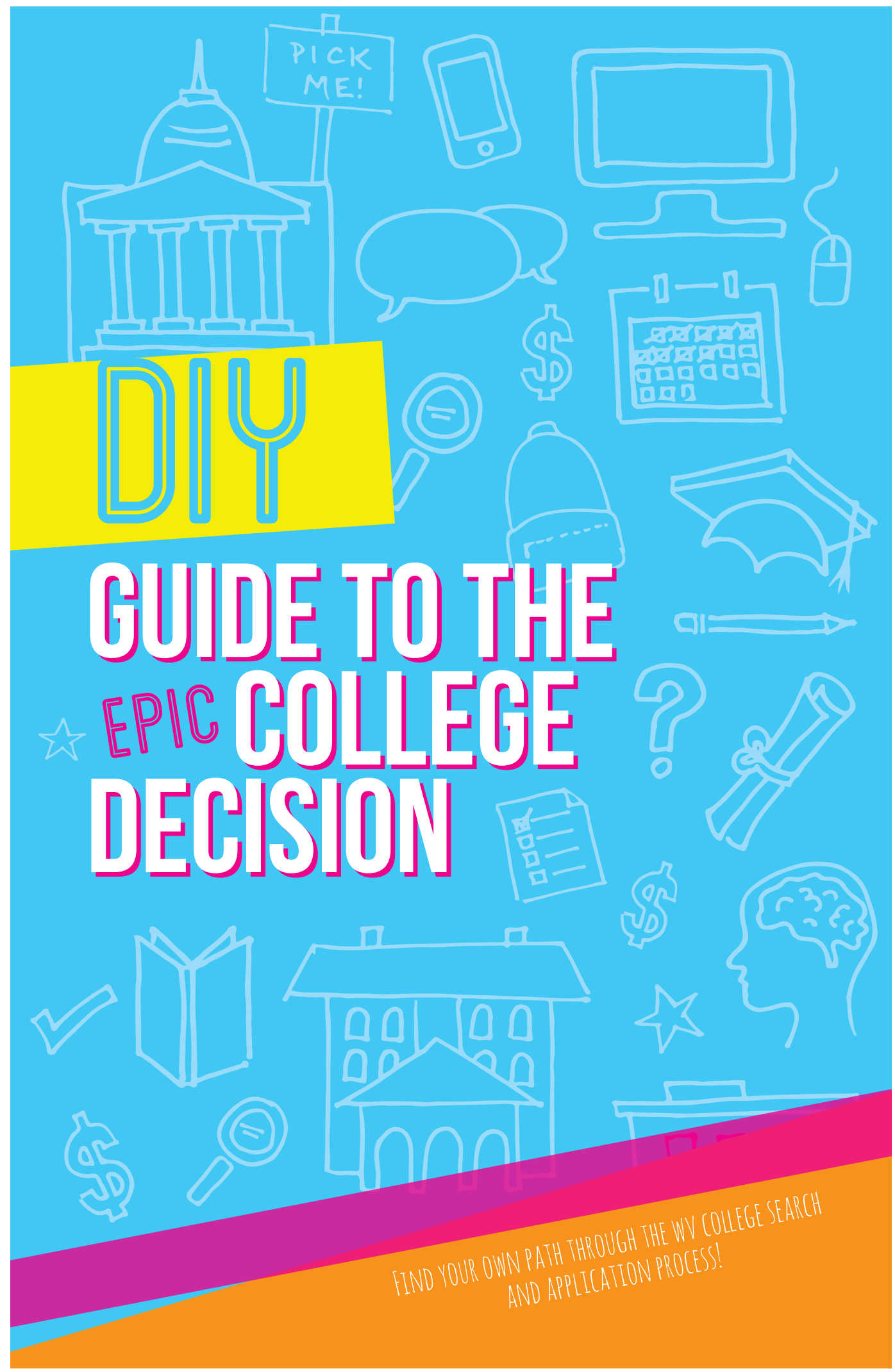

DIY Guide to the Epic College Decision. Booklet cover 


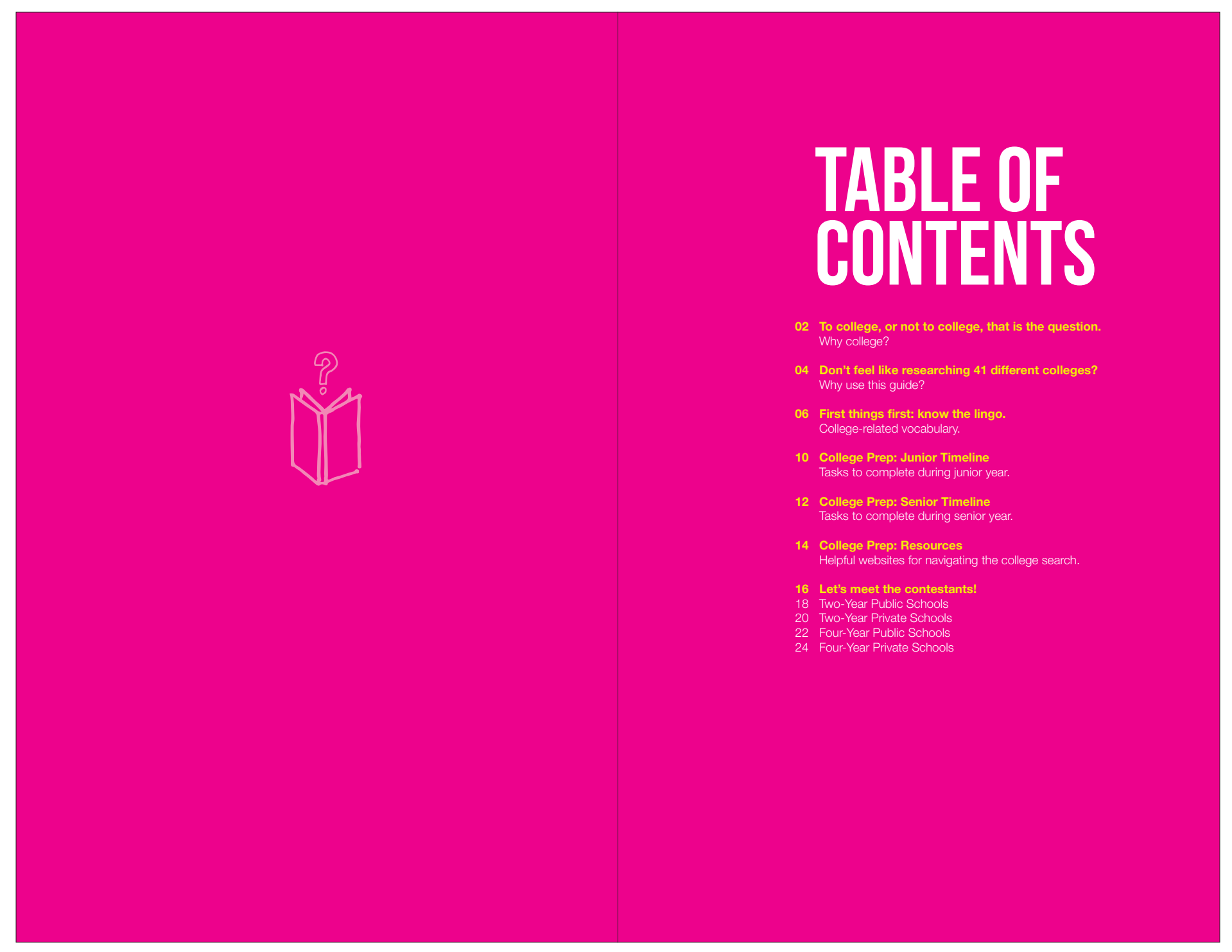

DIY Guide to the Epic College Decision. Booklet spread design. 


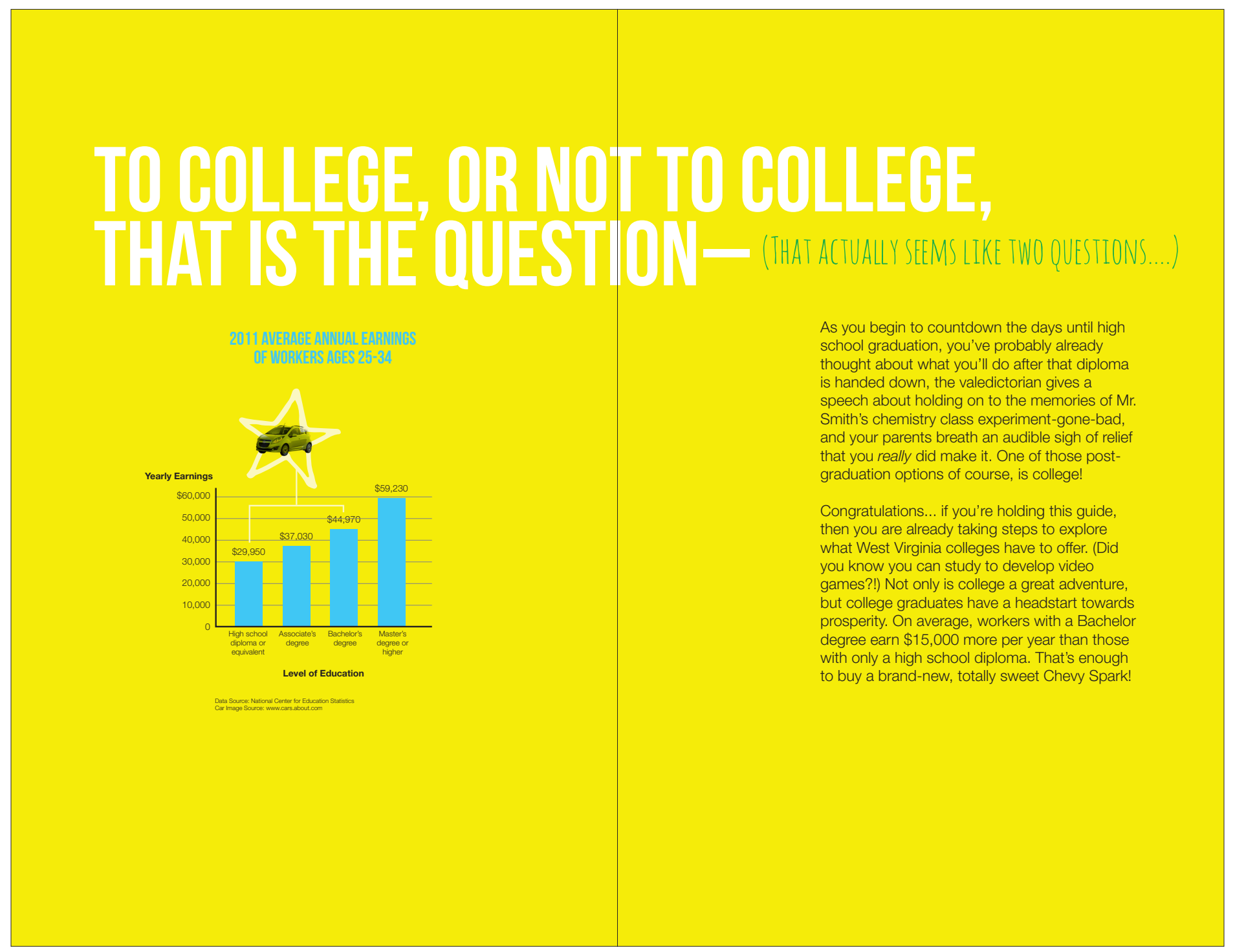

DIY Guide to the Epic College Decision. Booklet spread design. 


\section{DON'T FEEL LIKE RESEARCHING 41 DIFFERENT COLIEGES? \\ (Who Has TiMe FOR That??)}

Yes, West Virginia is home to forty-one colleges that award Associate and Bachelor degrees.

That's great because it means YOU have a lot of options, but not-so-great because it means you have lots of homework to find the best option.

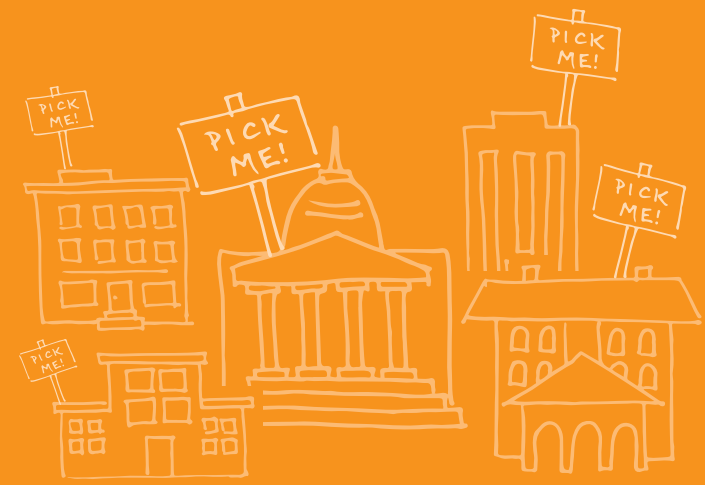

Making the transition from high school to college can be confusing- there are new terms to become familiar with, a to-do list that lasts through most of your junior and senior years of high school, and choice after choice that can only be made by you.

Maybe you receive mail, you see and hear commercials, and you visit websites to find a college that will fit. But with such variety, it can be nearly impossible to compare those options on a level playing field! That's where this guide comes in to save the day. Not only are we going to walk you through the basics of how to get to college, but we're also going to provide some super-handy tools that will help filter through those forty-one options to find the two or three that you're most excited about.

Let's dive in

DIY Guide to the Epic College Decision. Booklet spread design. 


\section{FIRST THINGS FFRST: KNOW THE LINGO}

Before you jump into the important things like which school has the best food*, it's helpful to have a clear understanding of a few important terms that you'll be seeing again and again.

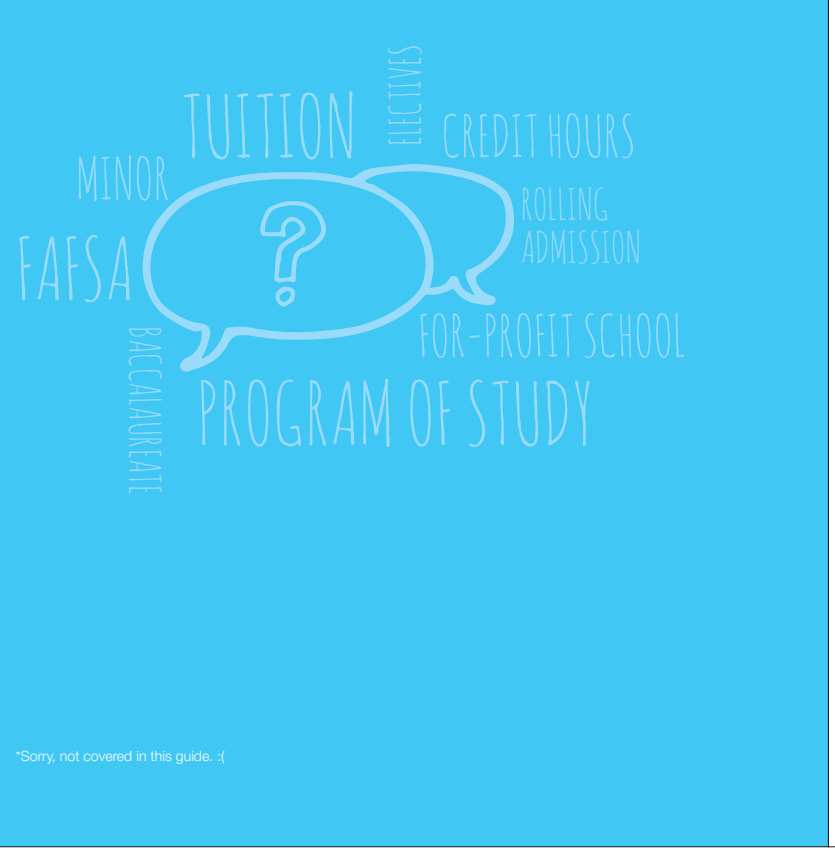

ASSOCIATE DEGREE typically completed in 2 years, or 60 credit hours requires taking basic courses like English and math along with courses specific to your program of study / can be converted into credit towards a Bachelor degree when transferring to a fouryear school / comes in varieties like A.A., A.S. and A.A.S

BACCALAUREATE typically completed in 4 years, or 120 credit [BACHELOR] DEGREE hours / along with basic courses like English and math you must complete several credit hours (ranging from 40-72) related to your program of study and several hours of electives / also referred to as an undergraduate degree / comes in varieties like B.A., B.S., B.F.A, and others

PUBLIC SCHOOL some of the school's financial support comes from the state government / each state has at least one public university / typically charge out-of-state students higher tuition and fees

PRIVATE SCHOOL__t the school's financial support comes mainly from student tuition, private donations, and the support of non-government organizations (often religious) / typically charge much higher tuition than public schools but can also provide significant financial aid to students who qualify

TWO-YEAR SCHOOL_ schools that only award certificates and Associate degrees / seek to prepare students for a particular occupation or to transfer to a four-year school/ also referred to as junior college or community and technical schoo

FOUR-YEAR SCHOOL schools that offer at least a Baccalaureate degree CLIBERAL ARTS COLLEGE,

UNIVERSITY] in a wide variety of programs / universities award baccalaureate, graduate (Master, Ph.D.), and professional degrees (M.D., J.D., etc)

FOR-PROFIT SCHOOL school that is in business to make money for it's shareholders or owners / typically offer fewer student services and activities than non-profit schools / non-profit institutions in contrast, do not have owners, but are guided by a Board of Governors who have diverse areas of expertise and are from the community / graduation rates a for-profit schools tend to be lower than those at non-profit institutions

DIY Guide to the Epic College Decision. Booklet spread design. 


\begin{tabular}{|c|c|c|c|}
\hline ENROLLMENT & $\begin{array}{l}\text { process of choosing courses for the upcoming } \\
\text { semester and then paying fees for the courses / } \\
\text { also refers to the total number of students who are } \\
\text { currently taking courses at that institution }\end{array}$ & $\begin{array}{r}\text { MAJOR/ } \\
\text { PROGRAM OF STUDY }\end{array}$ & $\begin{array}{l}\text { chosen field of study that requires a student to } \\
\text { successfully complete a specific number of credit } \\
\text { hours within that field / often differs from the actual } \\
\text { degree awarded (i.e. a student chooses to major } \\
\text { in graphic design, but the degree awarded for that } \\
\text { program may be called Bachelor of Fine Arts) }\end{array}$ \\
\hline TUITION & $\begin{array}{l}\text { amount charged for each credit hour or course } \\
\text { taken and only covers the fee for taking the class } \\
\text { itself, does not cover the fees for room and } \\
\text { board, books, technology fees or other charges / } \\
\text { typically lower for residents of the state (in-state) }\end{array}$ & MINOR & $\begin{array}{l}\text { a secondary field of study that requires a student } \\
\text { to successfully complete a specific number of } \\
\text { credit hours within that field, but on a lesser scale } \\
\text { than those required for a major }\end{array}$ \\
\hline ROOM \& BOARD & $\begin{array}{l}\text { amount charged to live in a dorm or apartment } \\
\text { provided by the institution and to cover meals in } \\
\text { the school's cafeterias or eateries / most schools } \\
\text { provide a variety of options to choose from }\end{array}$ & ADMISSIONS COUNSELOR & $\begin{array}{l}\text { school official who assists incoming students with } \\
\text { the application process by providing the most up- } \\
\text { to-date information about the school's offerings, }\end{array}$ \\
\hline \multirow[t]{3}{*}{ FAFSA } & \multirow{3}{*}{$\begin{array}{l}\text { Free Application for Federal Student Aid is a } \\
\text { standard application that students must complete } \\
\text { if they wish to receive loans, grants, or work-study } \\
\text { funds from the state or federal government / } \\
\text { most scholarships also require a student to have } \\
\text { completed the FAFSA in order to be considered / } \\
\text { must be completed each year of schooling }\end{array}$} & & $\begin{array}{l}\text { through the choices they must make in association } \\
\text { with that particular school }\end{array}$ \\
\hline & & UNDERGRADUATE & student pursuing a two- or four-year degree \\
\hline & & CREDIT HOURS & the way courses are measured in higher education \\
\hline \multirow[t]{2}{*}{ FINANCIAL AID } & \multirow{2}{*}{$\begin{array}{l}\text { broad term used to describe all of the } \\
\text { scholarships, loans, grants, and work-study funds } \\
\text { that a student receives in order to help pay for } \\
\text { college / can only be awarded to students who } \\
\text { complete the FAFSA and will vary depending on } \\
\text { many factors, including financial need, academic } \\
\text { performance, student classification, and available } \\
\text { funds }\end{array}$} & & $\begin{array}{l}\text { week spent in the classroom although this can vary } \\
\text { for lab, studio, or PE classes / most courses range } \\
\text { from 1-6 credit hours }\end{array}$ \\
\hline & & ELECTIVES & $\begin{array}{l}\text { courses a student may take outside the } \\
\text { requirements for their degree program in order } \\
\text { to braoden their education / most schools } \\
\text { require students to choose electives from certain } \\
\text { groupings like arts, sciences, or humanities }\end{array}$ \\
\hline ROLLING ADMISSION & $\begin{array}{l}\text { policy that gives students a very long window } \\
\text { of time to apply and be accepted to a school / } \\
\text { applicants are notified of acceptance or rejection } \\
\text { within a few weeks of applying, regardless of when } \\
\text { they apply / applying early to a school with rolling } \\
\text { admission can sometimes improve chances of } \\
\text { receiving a scholarship, allow for first choice in } \\
\text { housing options, and reduce stress associated } \\
\text { with deadlines }\end{array}$ & COMMUTE ONLY & school that offers no dorms or housing options \\
\hline
\end{tabular}

\section{DIY Guide to the Epic College Decision. Booklet spread design.}




\section{COLLEGE PREP JUNOR TIMELINE}

If you think planning all the details for a perfect prom night next spring is stressful, just wait until you start trying to coordinate the next two years of college preparation! Fortunately, you've got this guide and we're giving you a sneak peak of what needs to happen between now and your first college class.

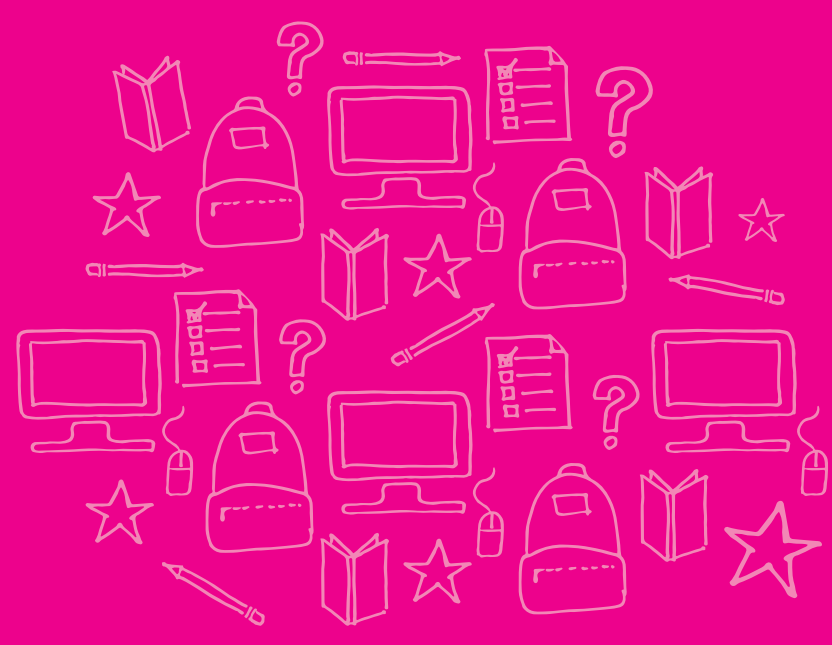

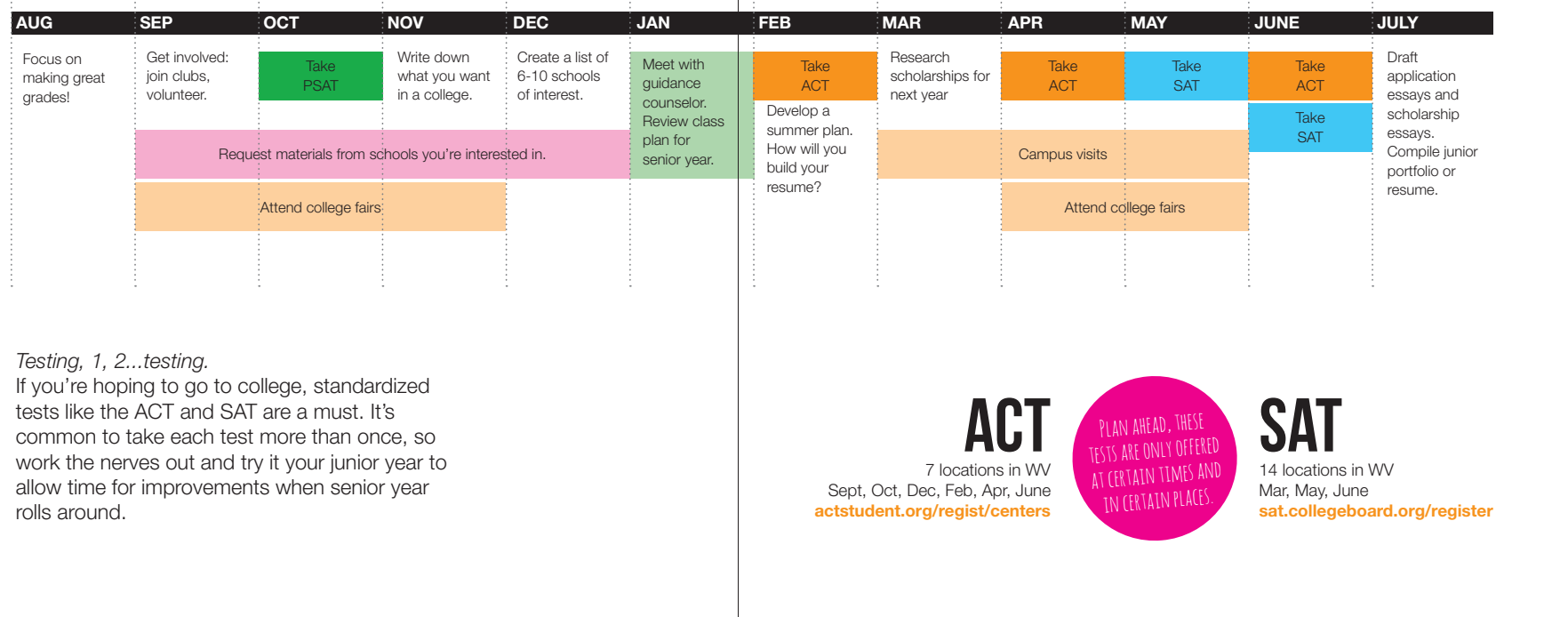

DIY Guide to the Epic College Decision. Booklet spread design. 


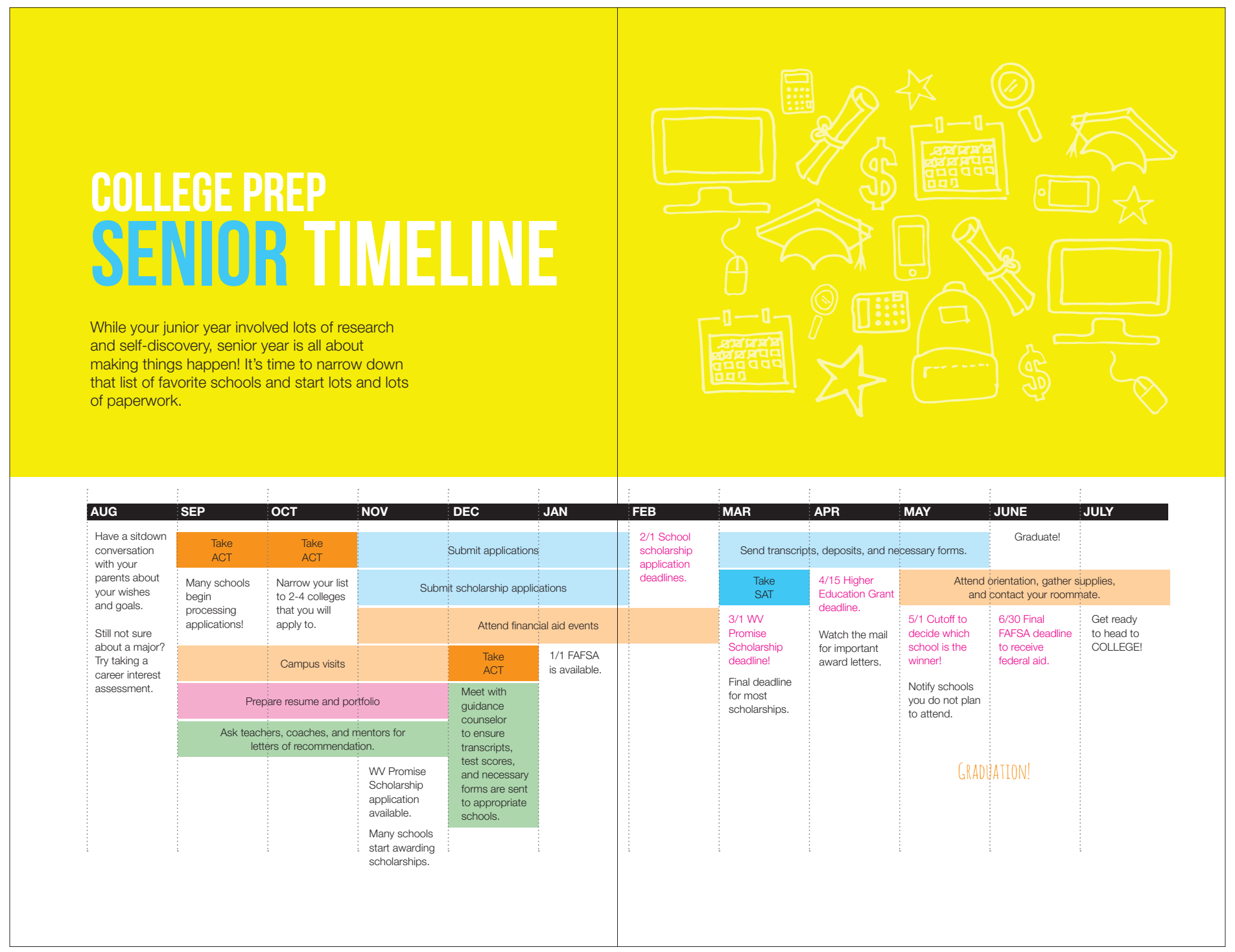

DIY Guide to the Epic College Decision. Booklet spread design. 


\section{COLLEGE PREP RESOURCES}

Are you ready to become BFFs with Google? Research for your junior English paper will be good practice for the work you'll need to do in preparing for college. But you don't have to start with a blank search bar! Here are some helpfu places to begin your research into scholarships, financial aid, test preparation, career options and more.

Some sites will ask you to create an account and profile so that you can be matched to suitable options and so that you can save information (like bigfuture.collegeboard.org). Other sites will ask you to create an account and pay for their services. Before taking this step, remember that there are literally millions of websites out there that offer planning resources for free. It's also important to be on the lookout for scams! $!^{\star \star}$

Last but not least, keep in mind that statistics from comparison sites can only tell you so much about a school. Use them to create a list, and then GO VISIT (!) those schools in person to see what they're really like.

${ }^{\star *}$ Fastweb.com and schoolsoup.com offer databases of scholarships and contests, but are also littered with scam
and contests that are too good to be true. Be carefull
WEST VIRGINIA RESOURCES

cfwr.com

Find basic info about all WV schools, financial aid planning resources,

WV scholarships and grants, blogs written by college students, and basic overviews of a variety of majors and career options. Hint: This is where you'll go for information and the application for the WV Promise Scholarship, the Higher Education Grant, and other state-sponsored scholarships.

wvde.state.wvu.us/counselors/students/scholarships.html A list of regional, state, and national scholarships, loans and contests. tgkvf.org Over 90 private scholarships and loans just for $\mathrm{W}$ residents.

mollohanfoundation.org

Scholarships, loans, and internship opportunities for WV residents.

\section{NATIONAL RESOURCES}

actstudent.org

Test preparation tools financial aid explanations and links, questions to ask during a campus visit and much more.

nces.ed.gov/collegenavigato

Search and compare WV schools by statistics like graduation rate, costs, athletics, campus security, etc.

colleges.usnews.rankingsandreviews.com/best-colleges

Each year, U.S. News \& World Report publishes rankings for more than 1,800 schools in the U.S. In addition to rankings, they provide numerous articles and tools to help students find the school that best fits their needs.

collegeresults.org

Create a customized, side-by-side comparison of schools to get many types of data including stats about acceptance rates and average test scores, race and data, inclung

\section{FREE APP}

evernote.com

Keep your research and to-do list in order with this free app. Save web pages, document your thoughts in video notes, and organize scans or images that are important. BONUS: Once you actually get to college, you'll be an expert Evernote user and can be the most organized freshman on campus!

DIY Guide to the Epic College Decision. Booklet spread design. 


\section{LET'S MEET THE CONTESTANTS!}
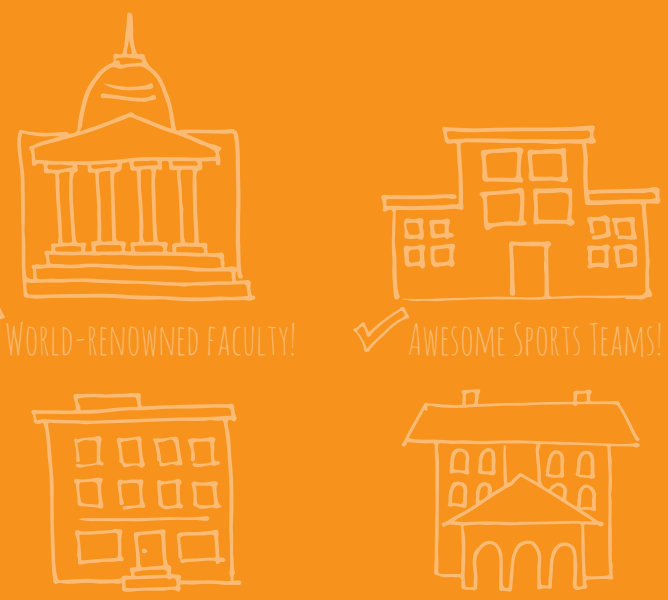

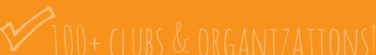

Just like a great reality show, the college search involves dozens of wildly different contestants each of them throwing themselves at you in an effort to walk away with the big prize: your enrollment! You may seek advice from friends and family only to get a different answer from each one of them.

That's why it is important for you to decide what you want out of your college experience! Then begin whittling down the list of potential schools based on whether they can deliver that experience at a cost you can manage, and in a location that you like. The rest of this guide and the decision-making tools in the other pocket of this folder will help you evaluate each schoolon a level playing field - to find the one where you can live happily ever after.

(AT LEASTFOR THE NEXTZ-LYFARS.)

DIY Guide to the Epic College Decision. Booklet spread design. 


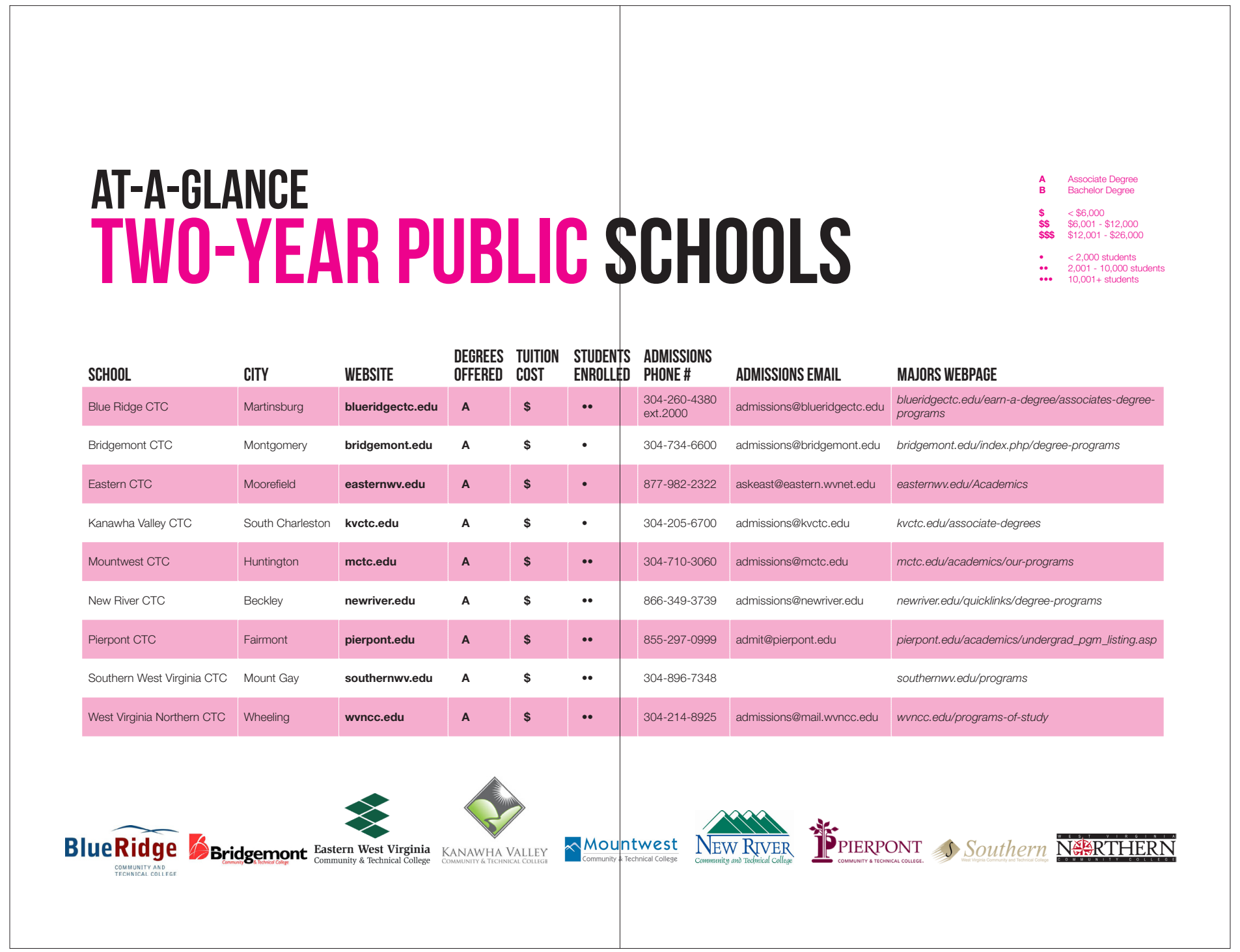

DIY Guide to the Epic College Decision. Booklet spread design. 


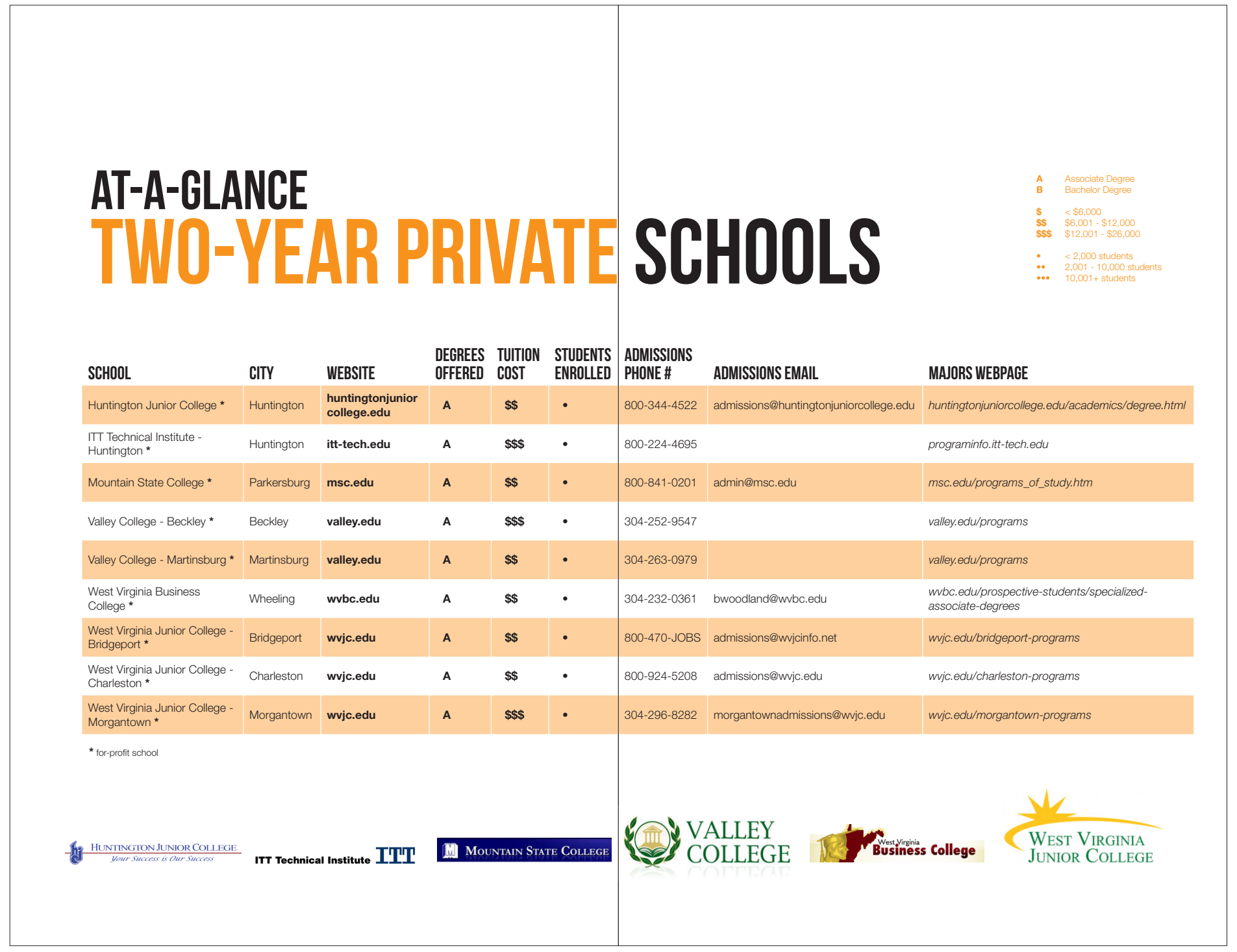

DIY Guide to the Epic College Decision. Booklet spread design. 


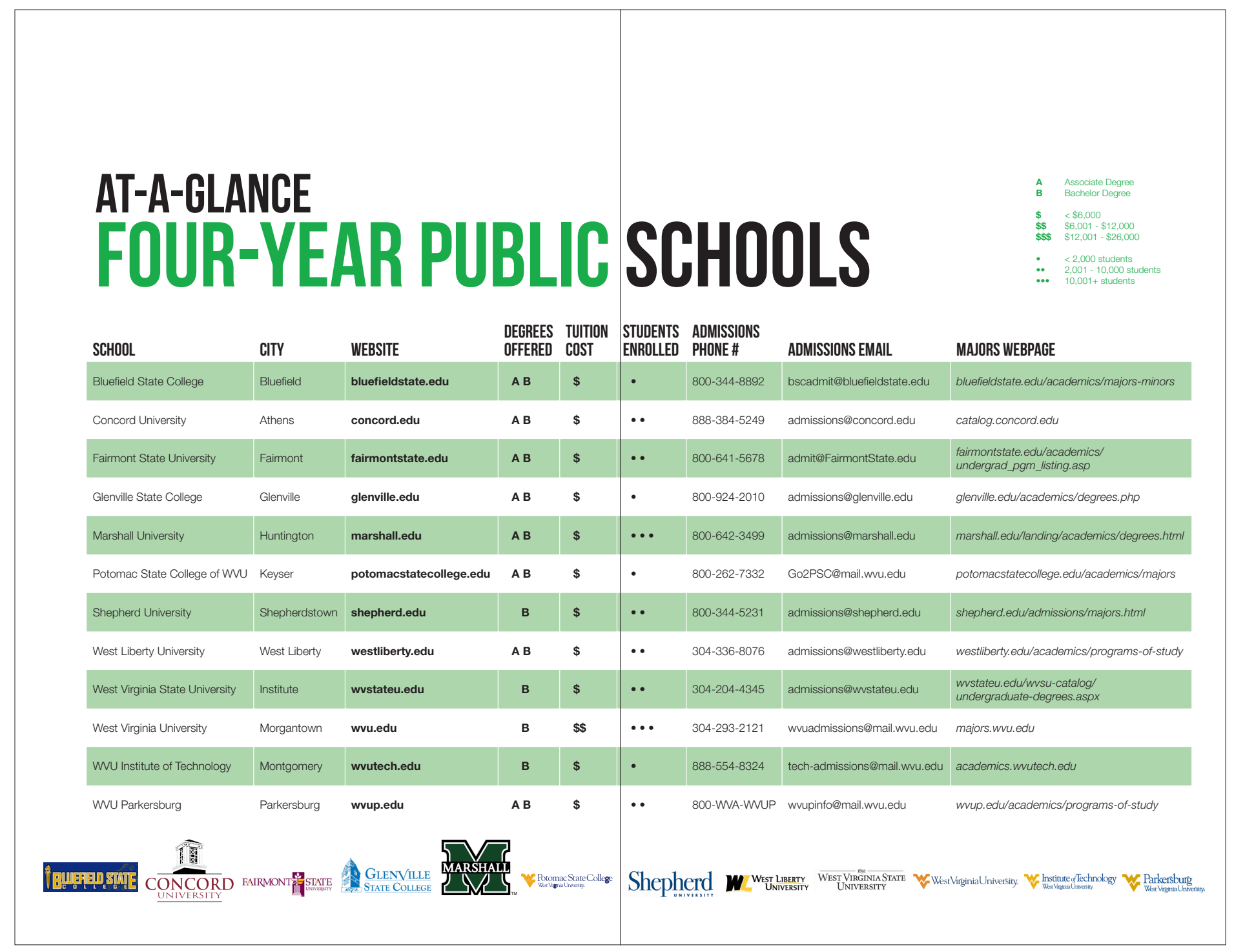

DIY Guide to the Epic College Decision. Booklet spread design. 


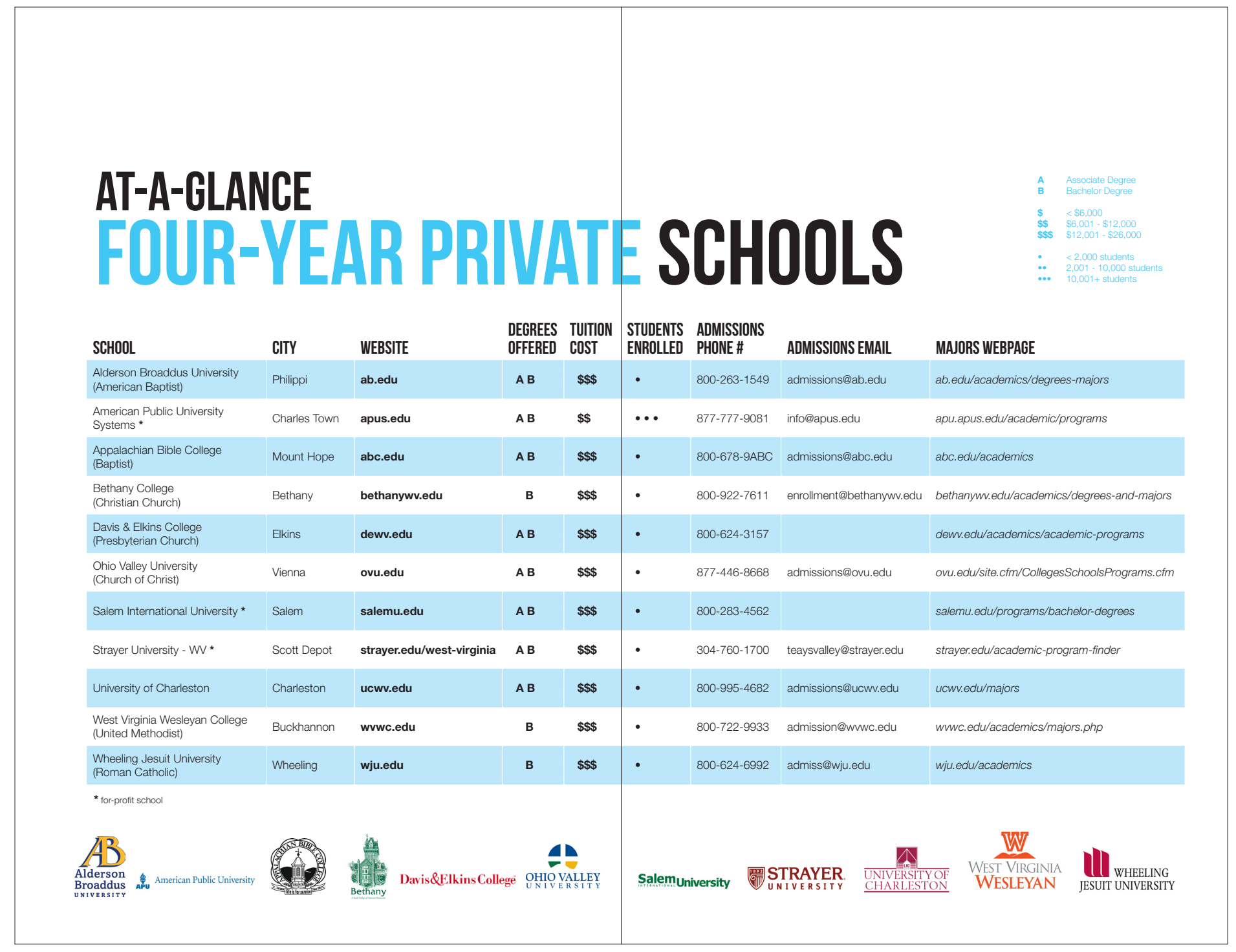

DIY Guide to the Epic College Decision. Booklet spread design. 


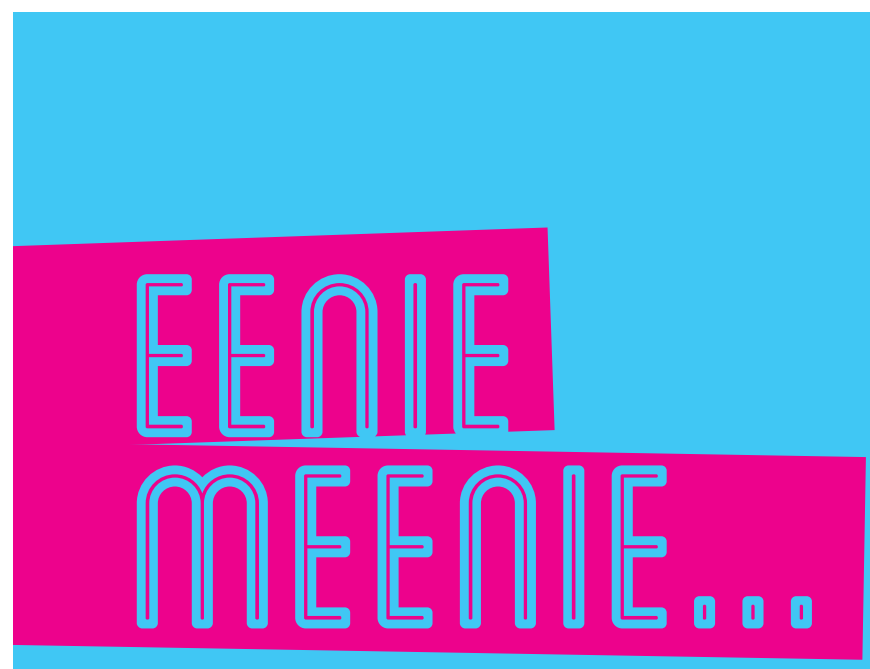

Now that we've covered the basics, it's time to take a more in-depth look at the selection of West Virginia colleges and what each has to offer. Choosing a school shouldn't be a game of eenie, meenie, minie, moe! The cards in the right pocket of this folder are tools that can help narrow forty-one schools down to five or six that best fit your own personal criteria.

We've done the legwork to round up information about:

\section{LOCATION \& SIZE \\ COST \\ TYPES OF DEGREES OFFERED MAJORS}

Use the tools in the order that's most interesting to you and use the provided area on the back of each tool to write your list of "maybes." Once you've narrowed the field, start visiting your favorite schools in person!

Data for this project was gathered from the U.S. Department of Education Institute of Education Sciences National Center for Education Statistics, the Bureau of Labor Statistics and from the school's individual websites. 


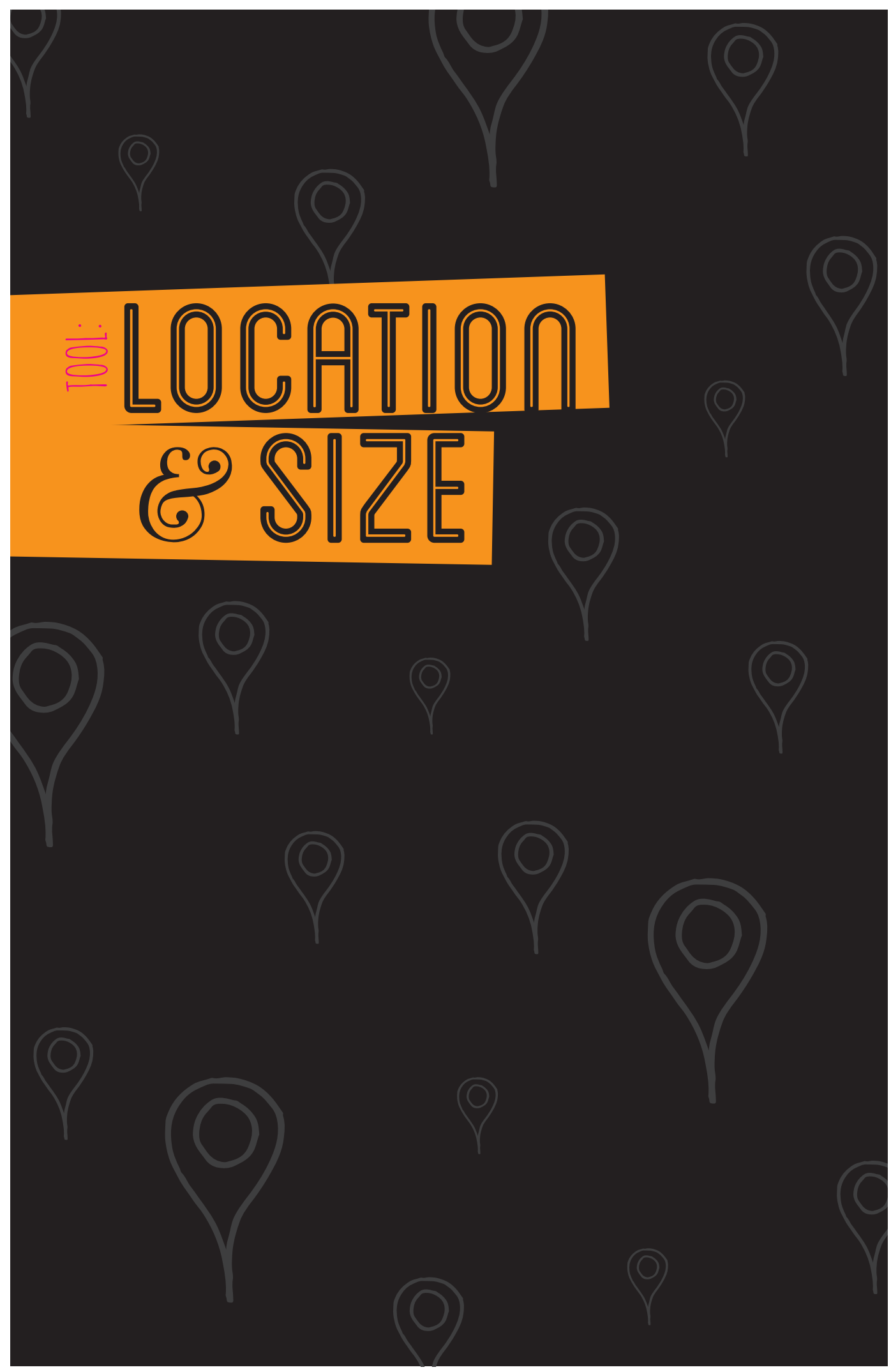

DIY Guide to the Epic College Decision. Infographic decision-making tool: Location \& Size. $5.5^{\prime \prime} \times 8.5^{\prime \prime}$ folded card, front cover 


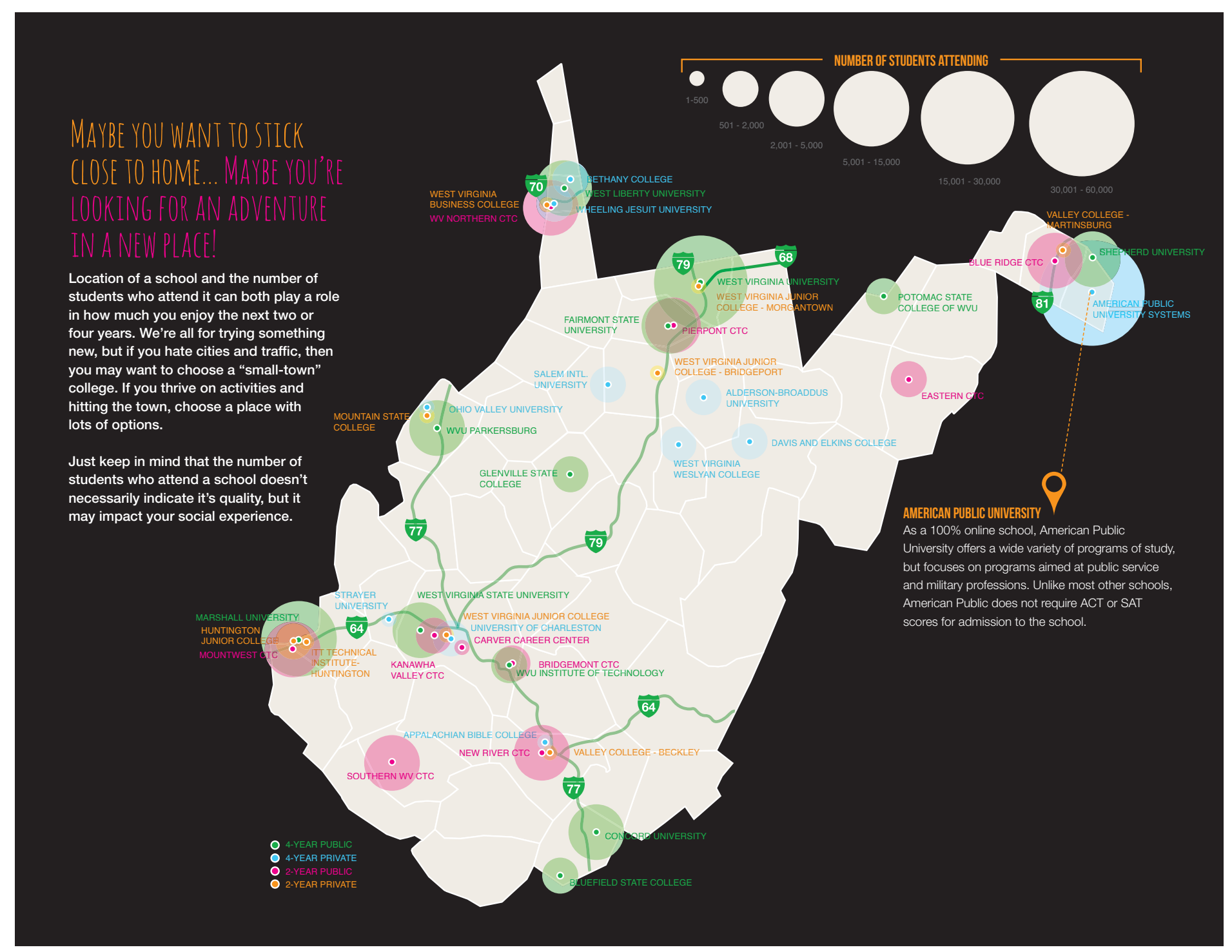

DIY Guide to the Epic College Decision. Infographic decision-making tool: Location \& Size. $5.5^{\prime \prime} \times 8.5^{\prime \prime}$ folded card, inside spread 


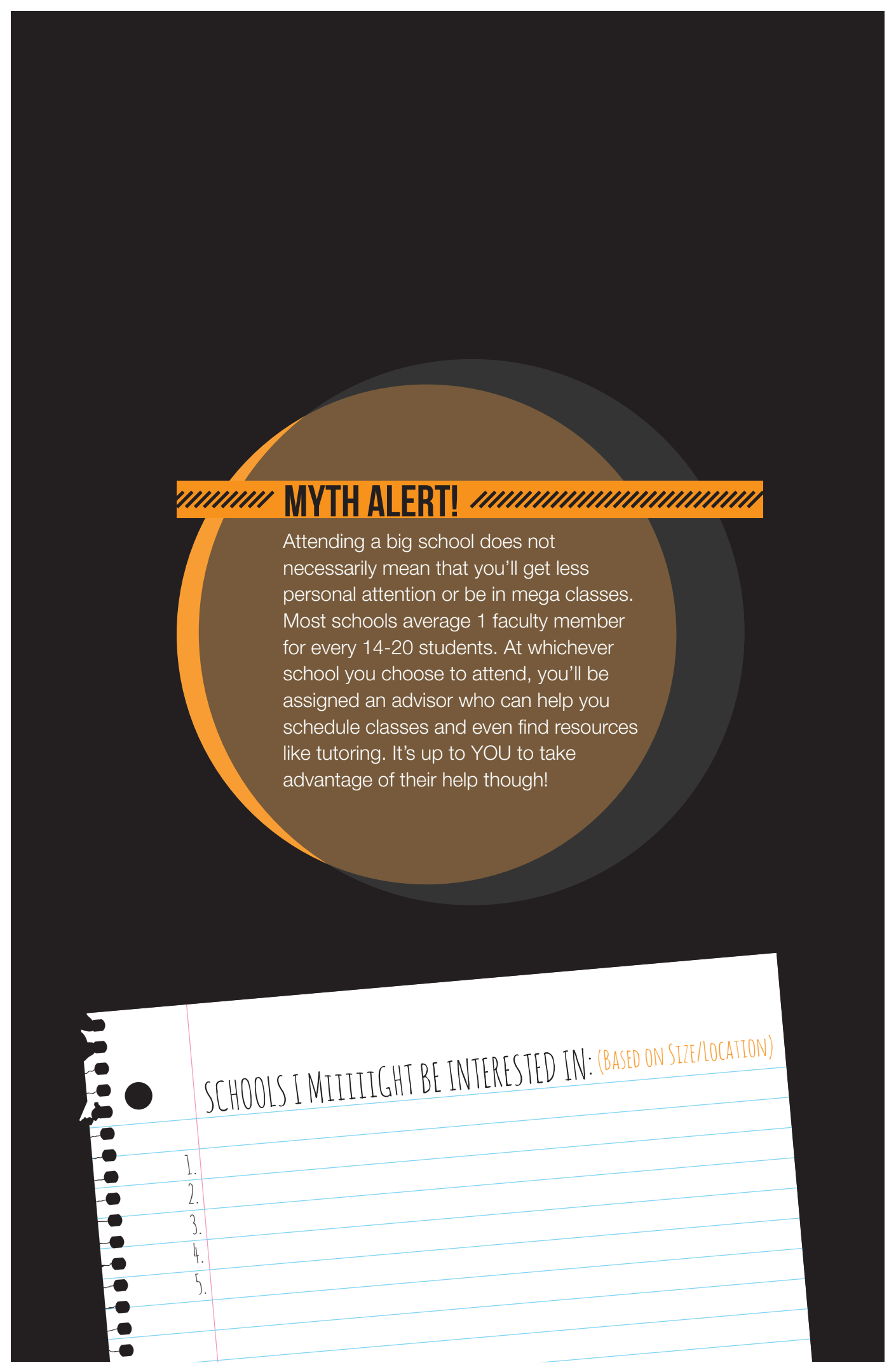

DIY Guide to the Epic College Decision. Infographic decision-making tool: Location \& Size. $5.5^{\prime \prime} \times 8.5^{\prime \prime}$ folded card, back cover 


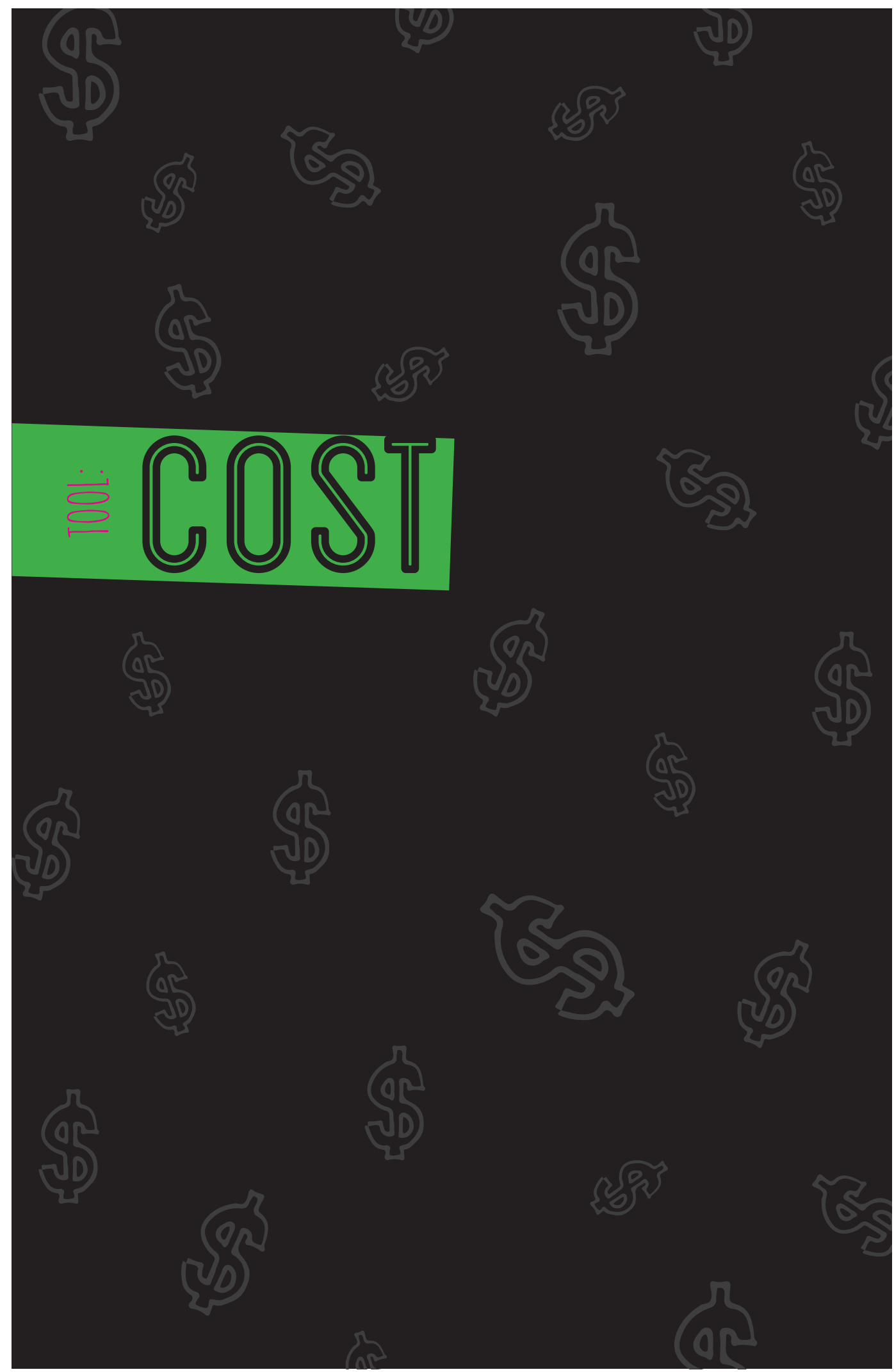

DIY Guide to the Epic College Decision. Infographic decision-making tool: Cost. $5.5^{\prime \prime} \times 8.5^{\prime \prime}$ folded card, front cover 


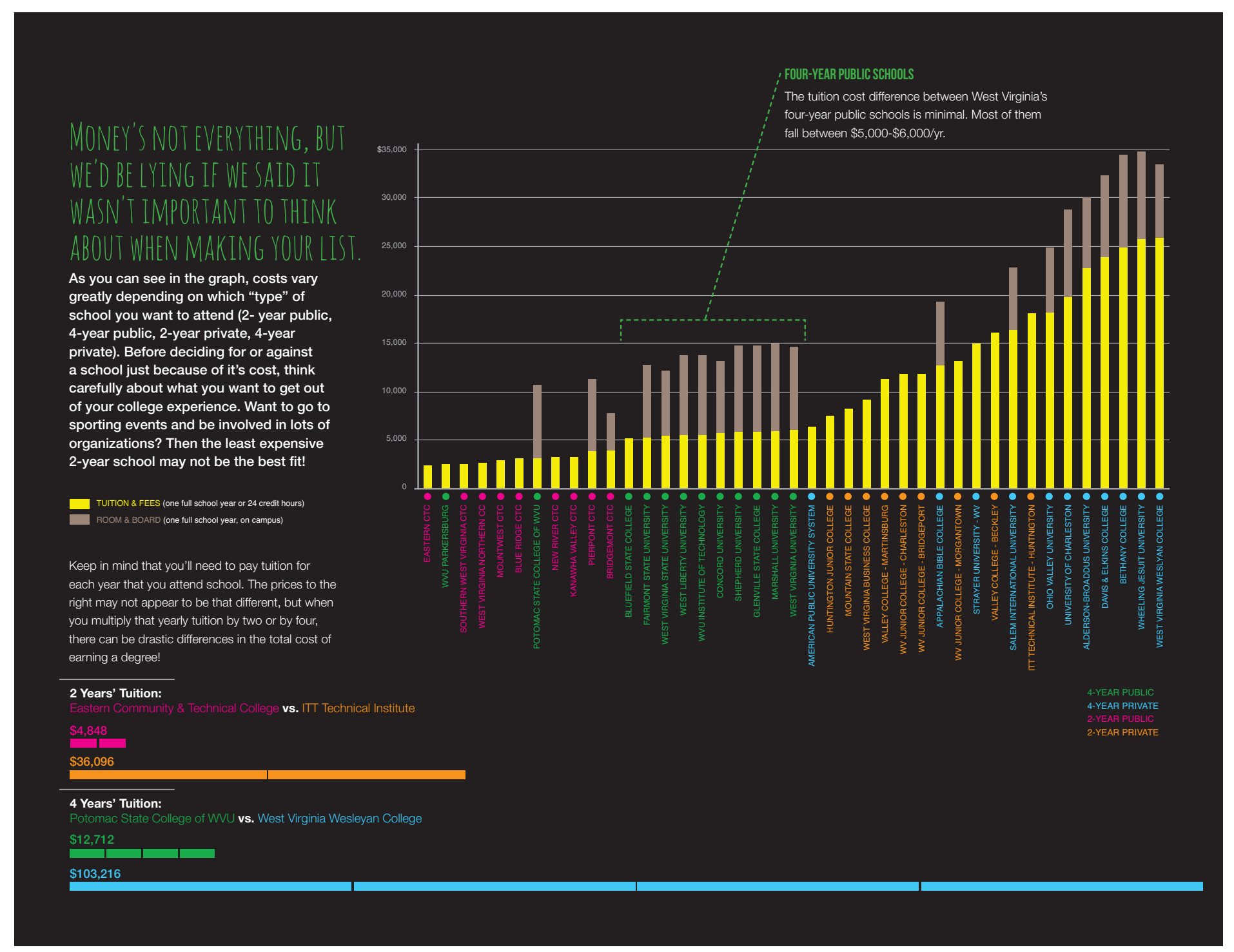

DIY Guide to the Epic College Decision. Infographic decision-making tool: Cost. $5.5^{\prime \prime} \times 8.5^{\prime \prime}$ folded card, inside spread 


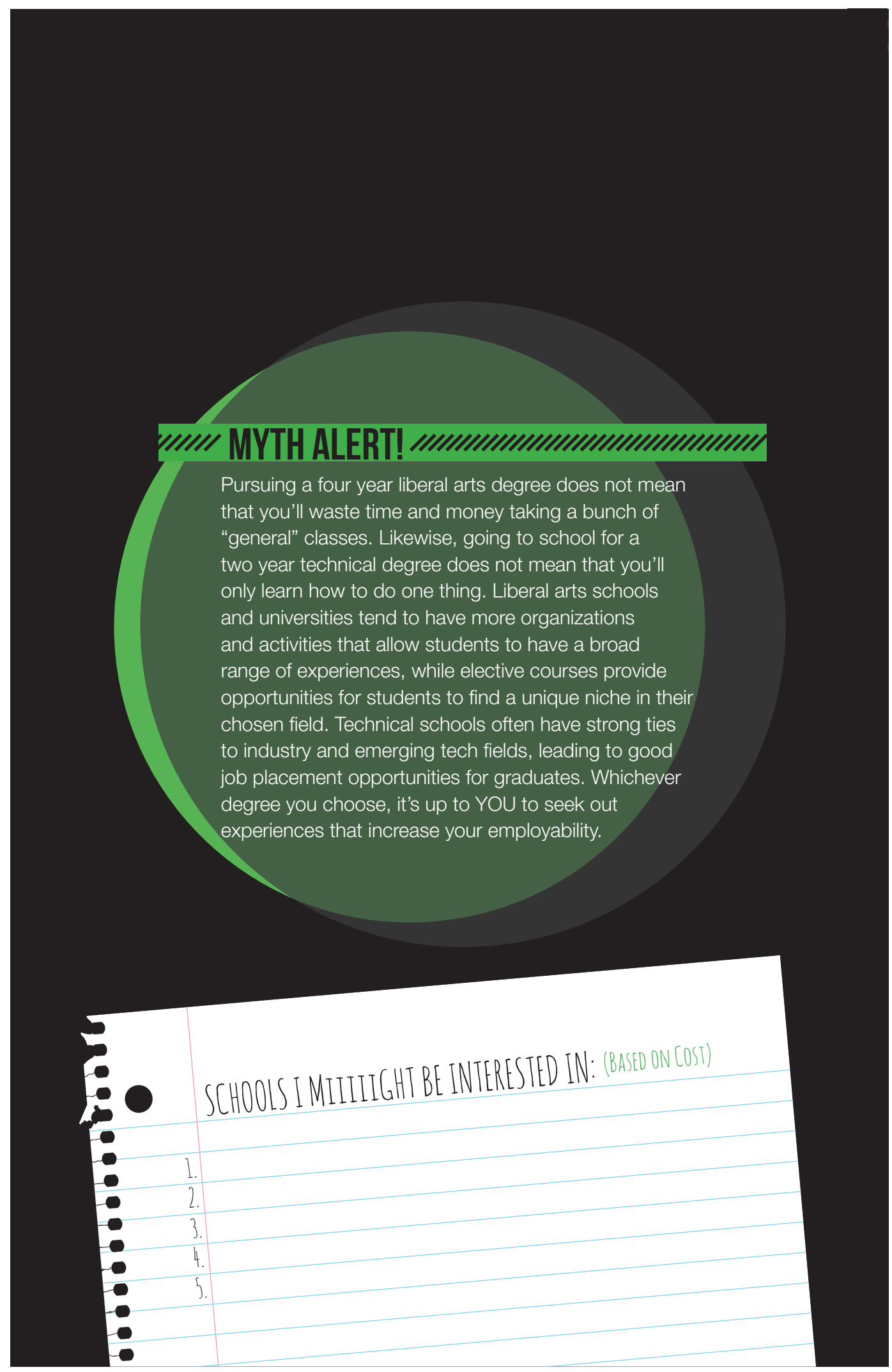

DIY Guide to the Epic College Decision. Infographic decision-making tool: Cost. $5.5^{\prime \prime} \times 8.5^{\prime \prime}$ folded card, back cover 


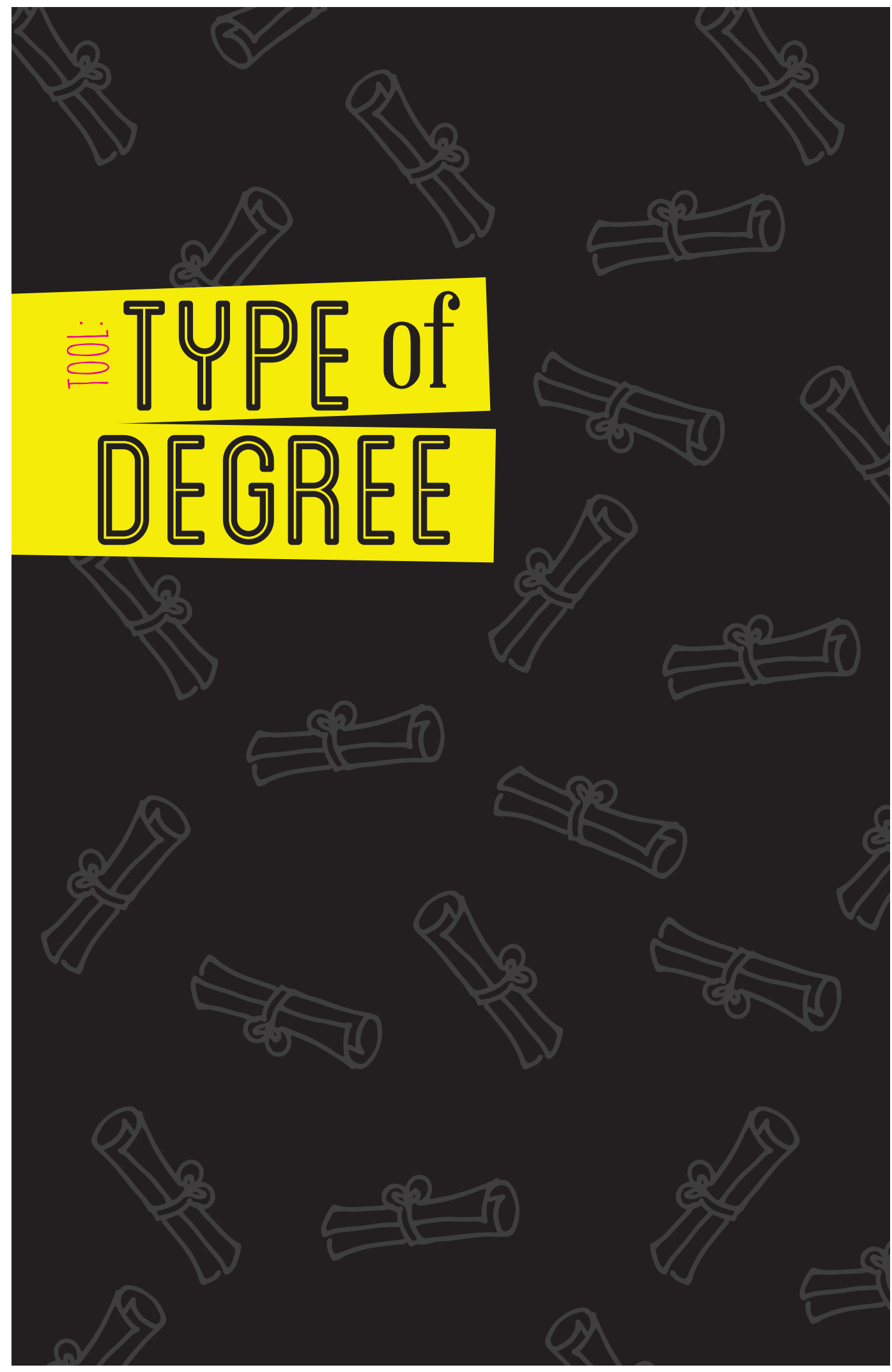

DIY Guide to the Epic College Decision. Infographic decision-making tool: Type of Degree. $5.5 " \times 8.5 "$ folded card, front cover 


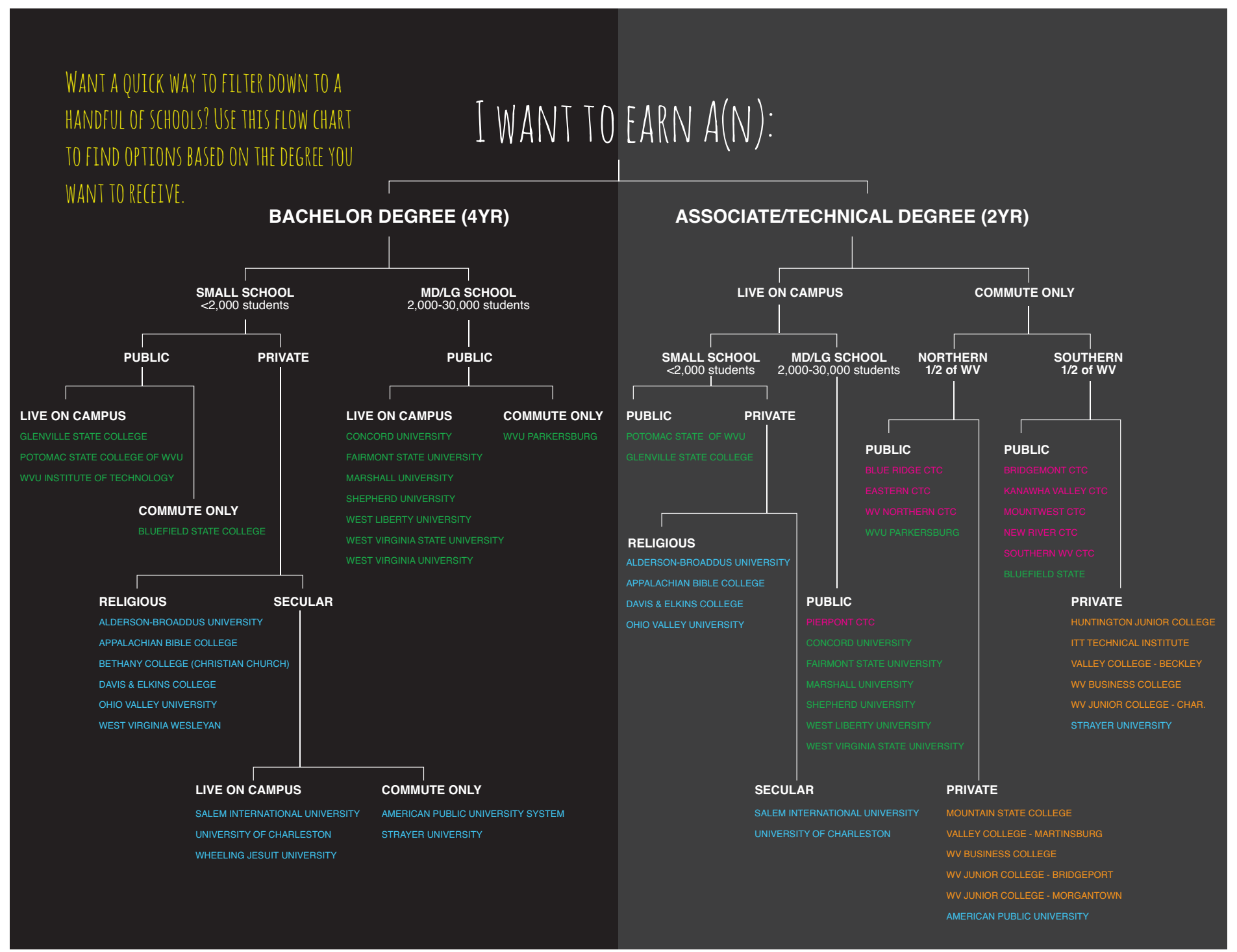

DIY Guide to the Epic College Decision. Infographic decision-making tool: Type of Degree.

$5.5^{\prime \prime} \times 8.5^{\prime \prime}$ folded card, inside spread 


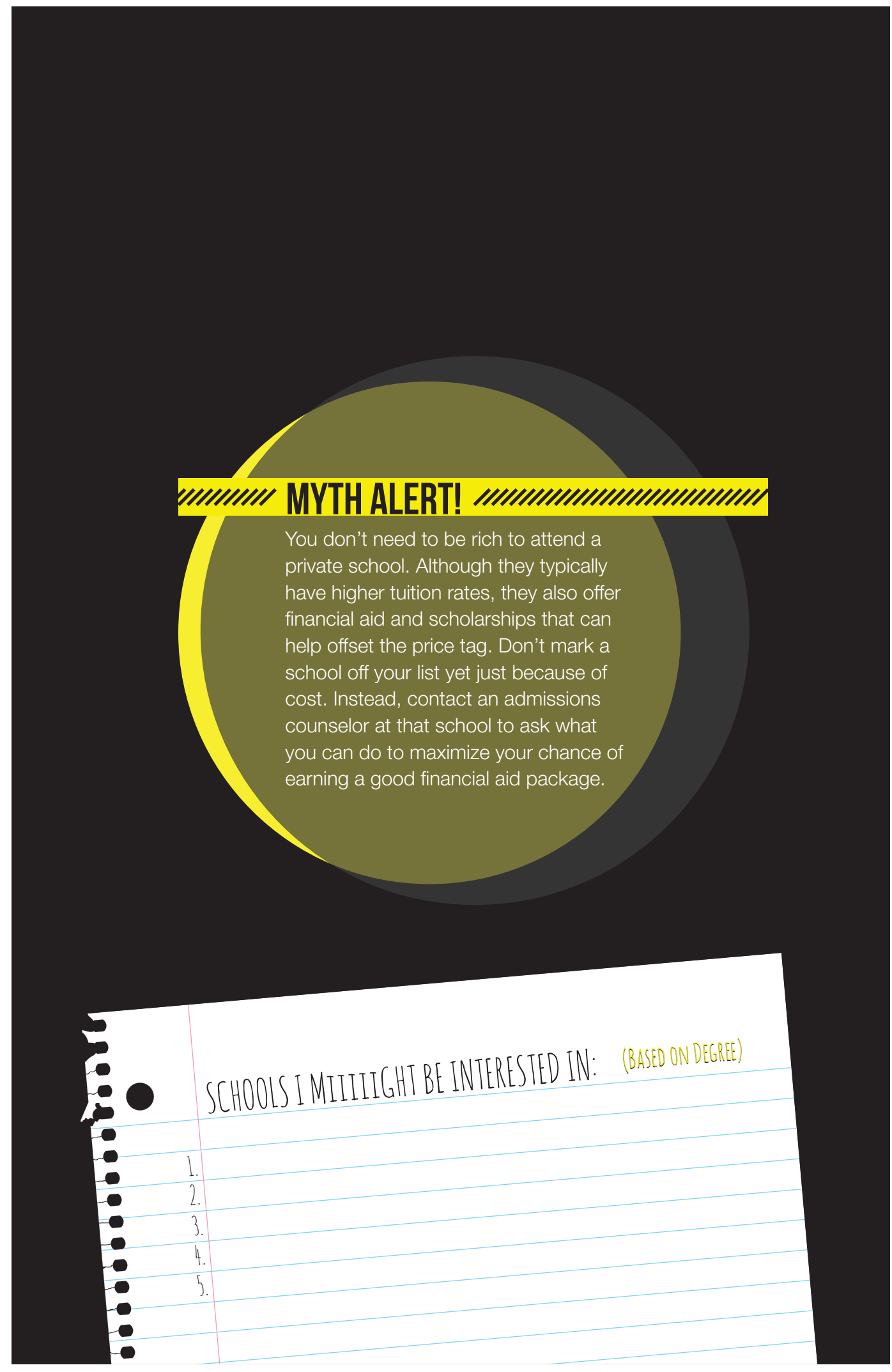

DIY Guide to the Epic College Decision. Infographic decision-making tool: Type of Degree. $5.5^{\prime \prime} \times 8.5^{\prime \prime}$ folded card, back cover 


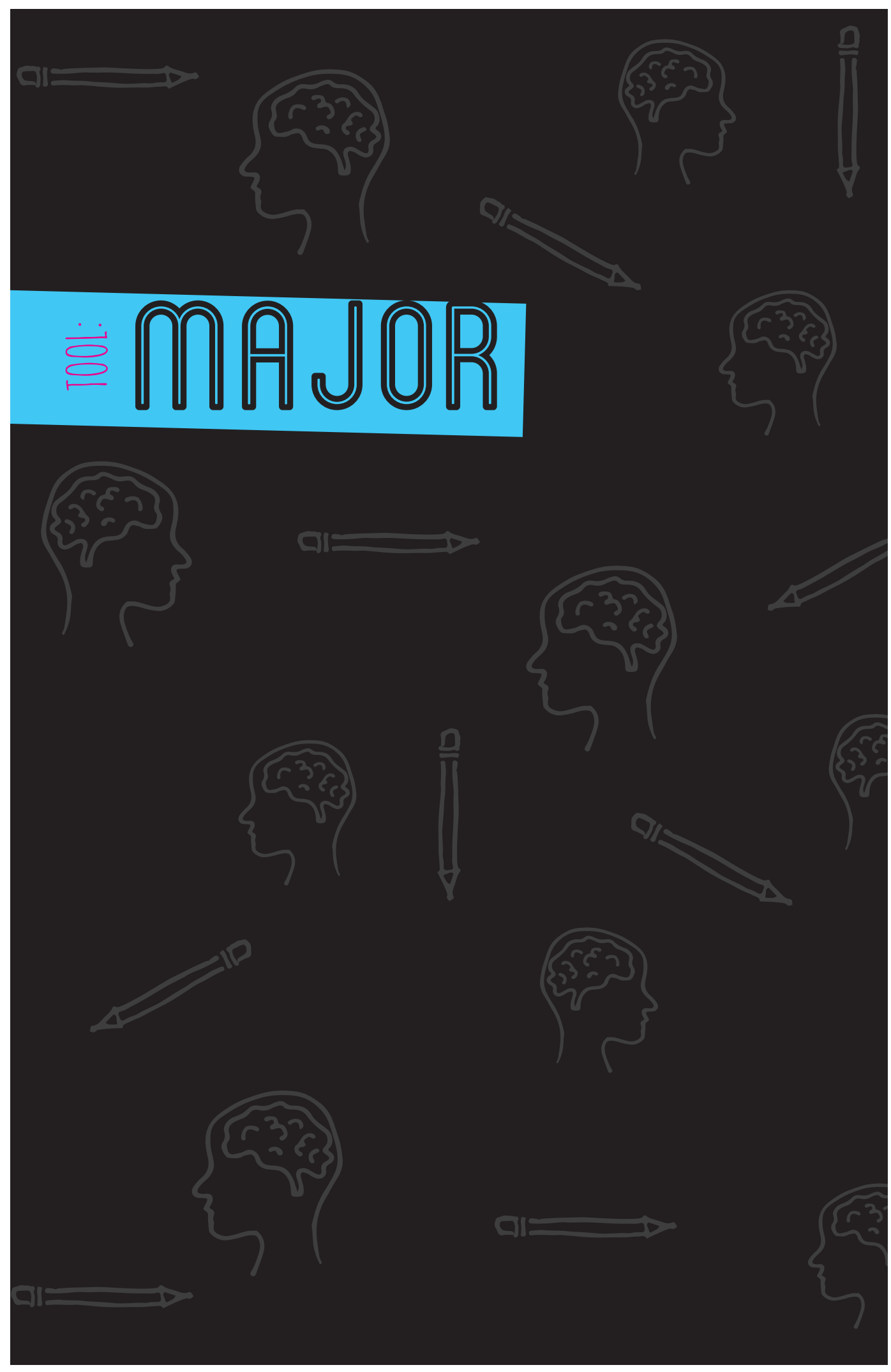

DIY Guide to the Epic College Decision. Infographic decision-making tool: Major. $5.5^{\prime \prime} \times 8.5^{\prime \prime}$ folded card, front cover 


\section{MANY STUDENTS WORK IN REVERSE}

\section{WHEN TRYTNG TO CHOOSE A COLLGE}

They 1) decide what career they want, 2) find degrees that lead to that career, and then 3) find schools with that major. According to the Bureau of Labor, these professions are among some of the fastest-growing for 2020, so we did the research to find out which WV schools can hook you up!

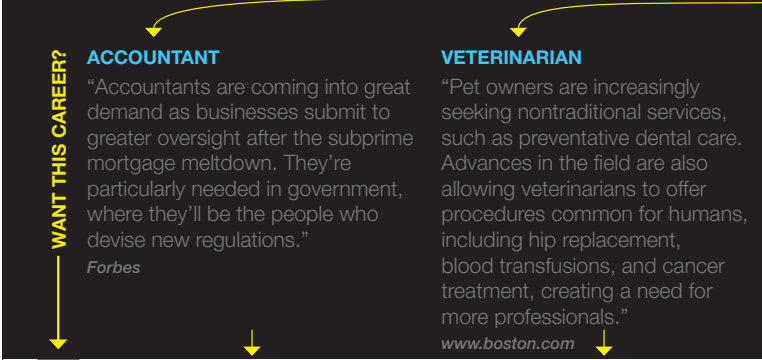

Vet schools do not require any certain major for admission, but a sciencerelated major is good preparation for the rigors of veterinary coursewor. mistry, Animal Science, Biochemistry, or designated Pre-Veterinary program

Software Engineering, Computer Science, or Computer Information Systems

HOT JOBS

of the

FUTURE

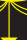

COMPUTER SOFTWARE

"Software developers are the

creative minds behind computer

applications that allow people to

underlying systems that run the

devices or control networks.

U.S. Bureau of Labor Statistics

1
OTHER GROWING PROFESSIONS

Data Scientist

Civil Engineer

Dental Hygienist

Financial Advisor/Financial Analyst Medical Scientist

Physician Assistant Home Health Aide

Network Systems Analyst Environmental Engineer

SYSTEMS SOFTWARE ENGINEER

do specific tasks on a computer or

other device. Others develop the

\section{BIOMEDICAL ENGINEER}

"In the coming decade, engineering

expected to offer the faste

growing area: biomedical

engineering. Jobs in this field, which

enters on developing and testing

health-care innovations such as

artificial organs or imaging systems,

The Wall Street Journal are expected to grow by $72 \%$.
Biomedical Engineering

A

Biomedical Engineering by preparin

with an undergraduate degree in

Engineering, Physics, Chemistry,

or Biology. to pursue a graduate program in

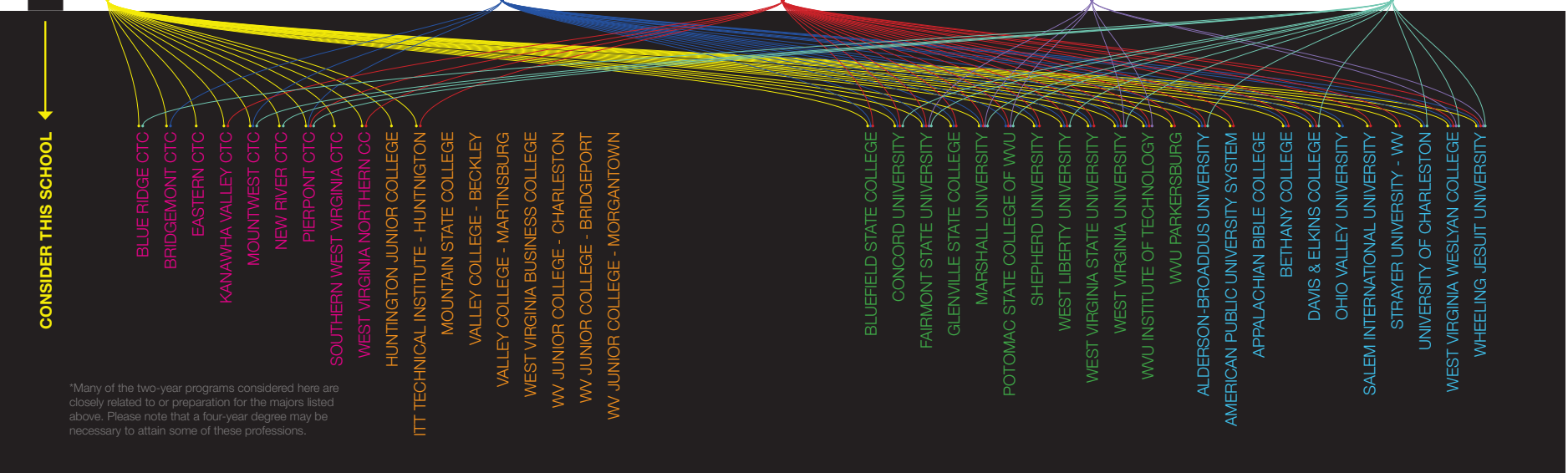

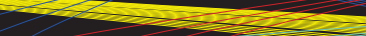

$>$

ATHLETIC TRAINER/ PHYSICAL THERAPIST

"The aging baby-boomer

population will require increased

physical care. At the same time,

growth in competitive sports and

itness is creating demand for those

trained in repairing participants."

New York Daily News

Athletic Training

Physical Therapy is a graduate-level program, but students can prepare by choosing undergraduate majors in Biology, Chemistry, a designated Pre-Physical Therapy program or other health or science degree.

DIY Guide to the Epic College Decision. Infographic decision-making tool: Major.

$5.5^{\prime \prime} \times 8.5 "$ folded card, inside spread 


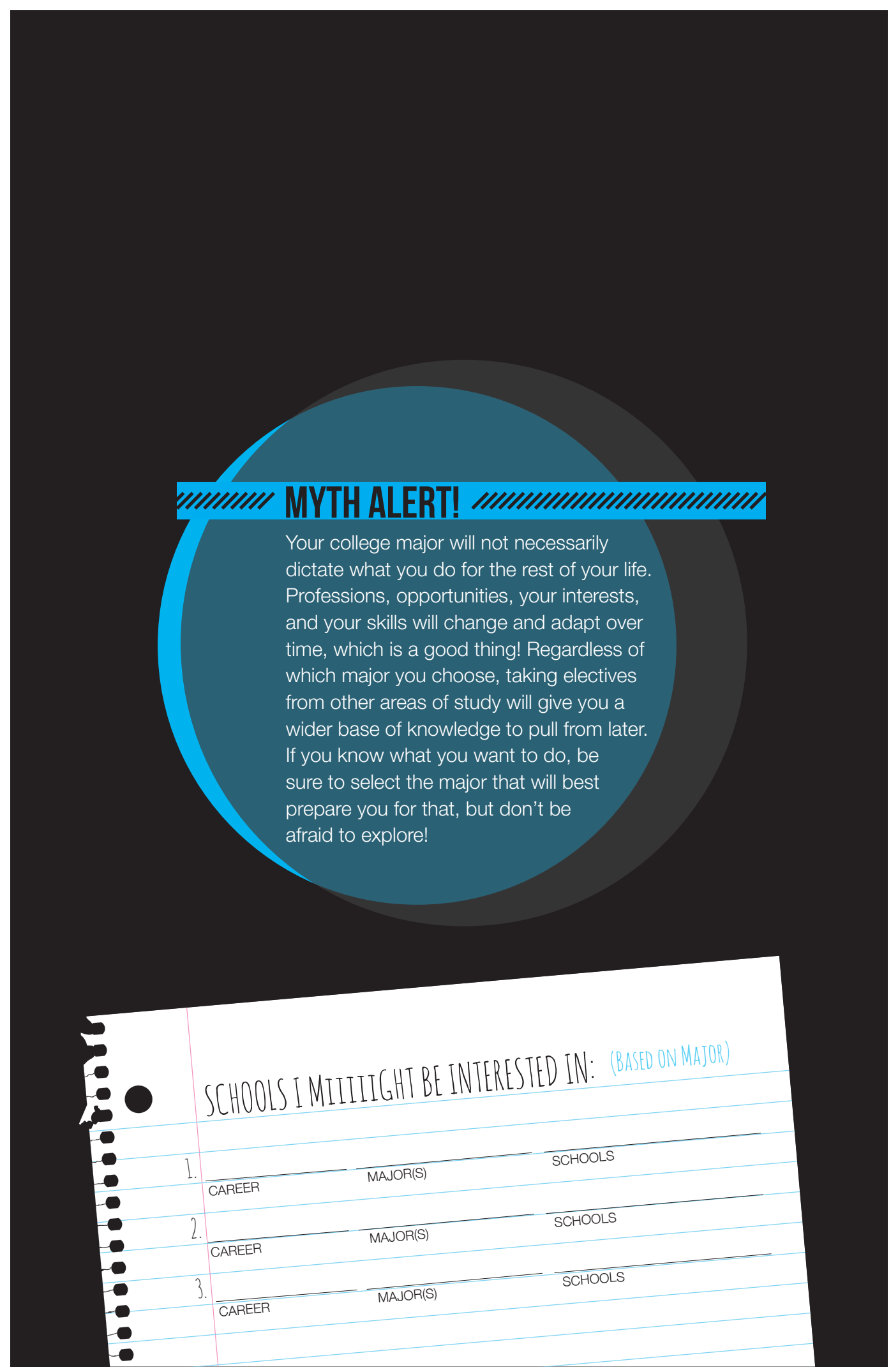

DIY Guide to the Epic College Decision. Infographic decision-making tool: Major. $5.5^{\prime \prime} \times 8.5^{\prime \prime}$ folded card, back cover 